
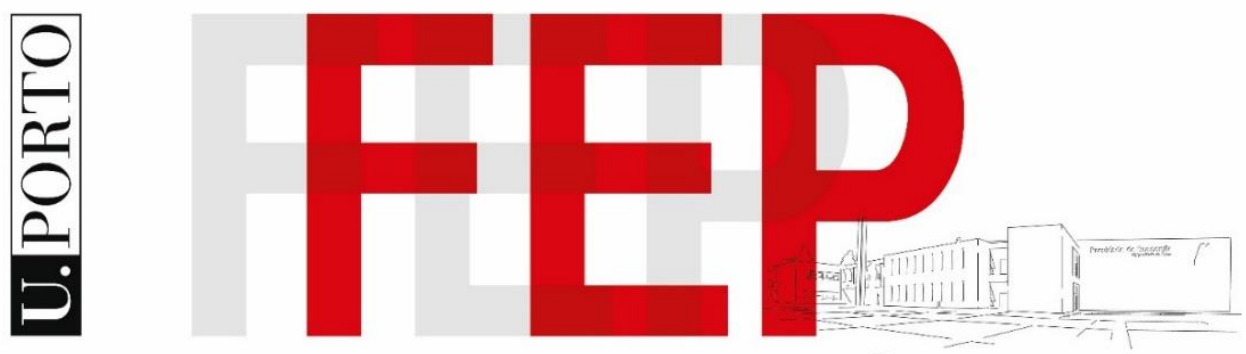

ECONOMIA E GESTÃO

\title{
The impact of brand love in building brand loyalty among young consumers
}

by

Ana Rita Martins de Sousa

Master Dissertation in Marketing

Advisor:

Amélia Maria Pinto da Cunha Brandão, PhD 


\section{Biographical Note}

Ana Rita Martins de Sousa was born on $27^{\text {th }}$ june of 1992.

In 2013 she graduated from Faculdade de Letras da Universidade do Porto with a Licenciate Degree in Communication Sciences.

During her curricular experience, she did an internship in Jornal de Notícias, in the online section of the publication. She also developed some pieces to International and Culture sections. Also, in the same year, she collaborated as a Communication and Marketing Assistant in AP | PORTUGAL - Language Services, a translation company based in Oporto, Portugal. She also collaborated with the International Relations and Information Department (IRID) of the company, responsible for the institutional and business relations with language service companies worldwide.

In 2014, she started frequenting the Master in Marketing of Faculdade de Economia da Universidade do Porto, which includes the following Master Dissertation.

In 2016, she was selected as one of the finalists representing Faculdade de Economia da Universidade do Porto at L'Oreal Brandstorm Challenge.

In the same year, she started an internship in Marketing Direction of Sonae MC. Currently, she is Brand Manager Assistant in the same marketing department representing KASA, Bagga, Contemporal and Seguros Continente brands. She's also responsible for the communication of Sonae's commercial galleries. 


\section{Acknowledgements}

First, and above all, I would like to express all my thankfulness to my supervisor, Professor Amélia Maria Pinto da Cunha Brandão for all the support, help and advices during this journey which has not been easy all the way. She made sure I was always kept me inner strength and never give up.

To my family, in particular to my parents and siblings, for being a stable rock all along the way. They always believed in me and helped me during the most difficult parts of this journey. Thank you for all the right-hug-time.

To all my friends, whom I have been neglecting for the past months. Thank you for always believing and supporting me and for being always comprehensive about all the times I couldn't make it to social events. To Eduardo, Helena, Lúcia, Marta, Filipa, Margarida, Joana and Inês a special thank you for all the times they offered to help or just to know how I was doing. Their recognition and support, kept me on track.

Last but not least, to Pedro. Thank you for always believing in me even when I didn't. Thank you for the support in the moments of more stress or the times I became so badtempered and blue. Thank you for being suportive about all the things I had to make you miss. 


\begin{abstract}
Purpose - The purpose of this investigation is to understand how brand love can influence brand loyalty among young consumers, considering engagement constructs and social networks. Is brand love effective in building true brand loyalty? Does interactive engagement with brands and brand love contribute to build brand loyalty? Does interactive engagement on social networks reflect millennials love of brands? These are some of the dimensions we try to answer with this study that covers a never seen model covering several constructs of the extant literature with the main focus on Brand Love.
\end{abstract}

Research design/ Methodology - To collect data we conducted two online surveys. These two surveys were identical, only differentiating for covering two different brand categories: Fashion and Technology. The objective to them compare different studies. The surveys were sent by email to all Portuguese universities, but there are only track of being distributed in Universidade do Porto and Nursering School of Porto. The survey was also distributed in Facebook in an event created for this purpose. The analyses of results and hypotheses test were made by using the Structural Equation Model (SEM). The comparison between studies were made using multi-group analysis.

Findings - It was found a positive direct impact of all constructs between the relations we created with this model. Consequently all hypothesis were tested. Consumers' Brand Related Social Media Content was proved to have a direct impact on Social Interactive Brands and Brand Loyalty. Social Interactive Brands were proved to have a direct impact on Emotional Attachment and Self Expressive Brands which also proved direct impact on Brand Love. Brand Love for instance was proved has been directly connected with Brand Loyalty and Word of Mouth and Brand Loyalty also, directly impacts Word of Mouth.

Research contribution - The main contribution of this investigation to research is the new model proposed. Besides all relationships are not proved in literature, in this investigation we proved that all the relations established are validated with significant correlations. The results aim to provide tools for brand managers adopt important strategies concerning brand love in social media.

\title{
Keywords
}

Brand Love • Brand Loyalty • Brand Emotion - Brand Attachment • Word-of Mouth • Self-Expressive Brands • Consumer Engagement $•$ Social Interactive Brands 


\section{Table of Contents}

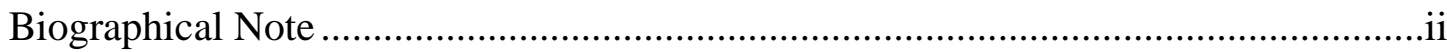

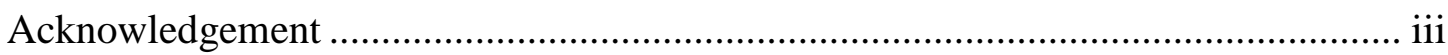

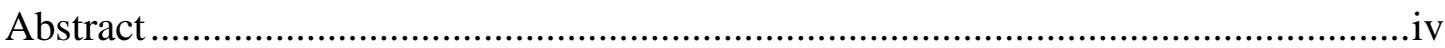

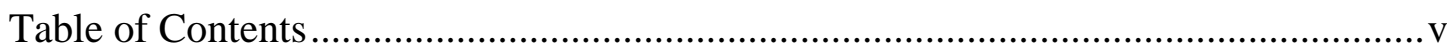

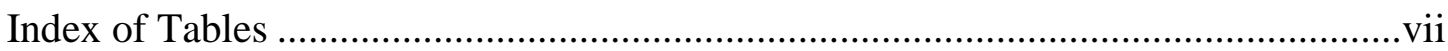

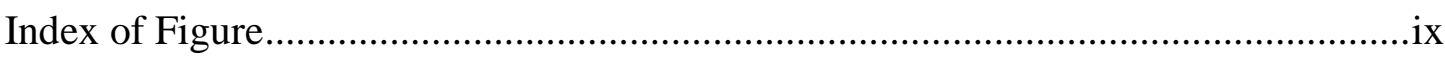

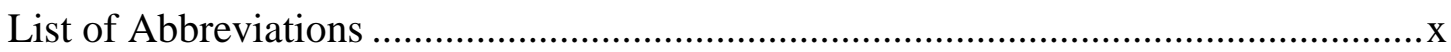

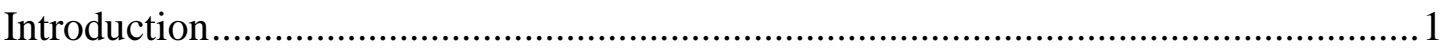

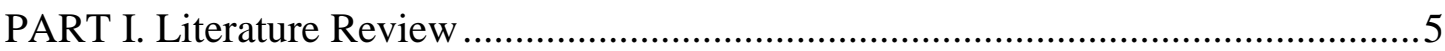

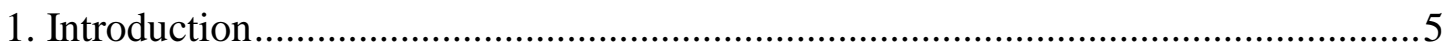

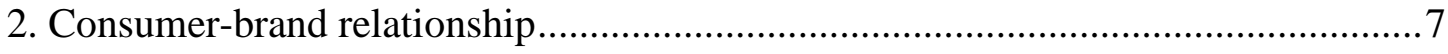

2.1. Why consumers create bonds with brands .................................................... 7

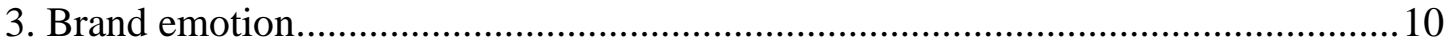

3.1. Emotion constructs that better explain the existence of attachment toward brands and its antecedents and outcomes - Brand Love, Brand Attachment and Brand Passion

4. Brand Loyalty 17

4.1. Understanding brand loyalty as a potential main outcome of brand love ........... 17

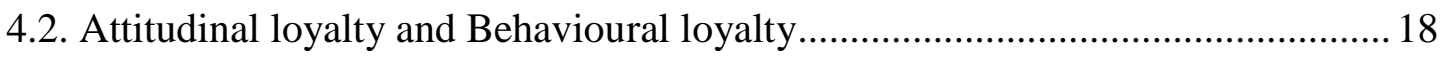

5. Consumer Engagement: how are we attracted to brands? .................................... 19

5.1 Young consumers and their relationship with brands ...................................... 19

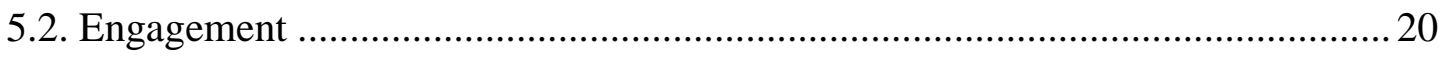

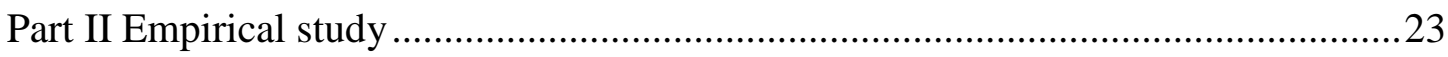


6. Methodology .23

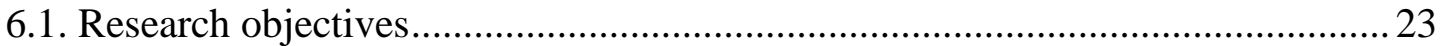

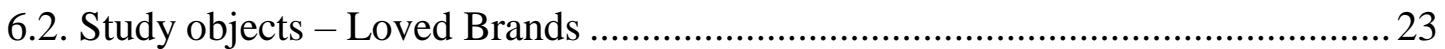

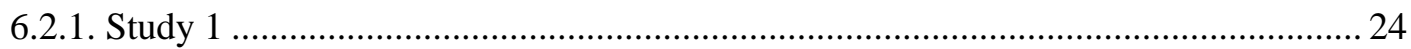

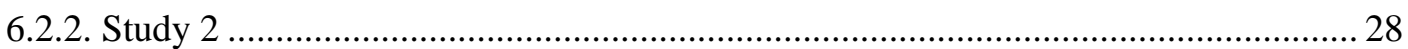

6.3. Conceptual framework and hypothesis formulation........................................ 30

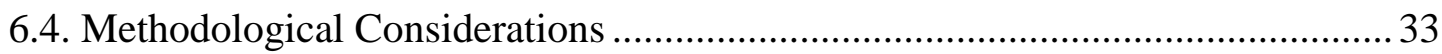

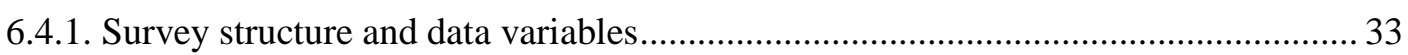

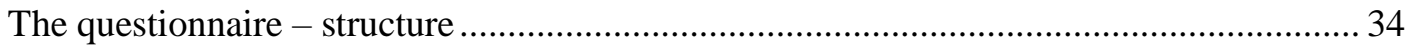

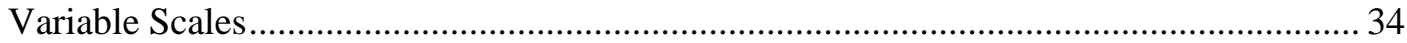

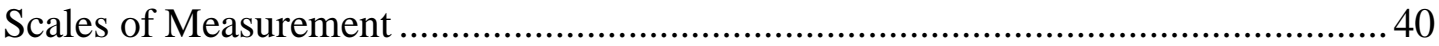

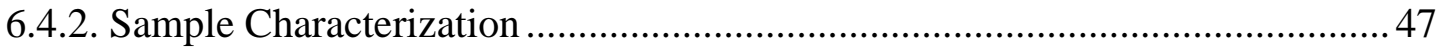

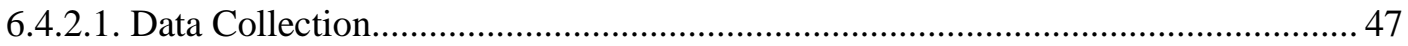

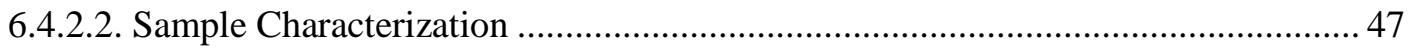

6.5. Structural Equation Modelling (SEM) ............................................................. 51

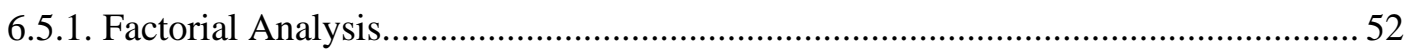

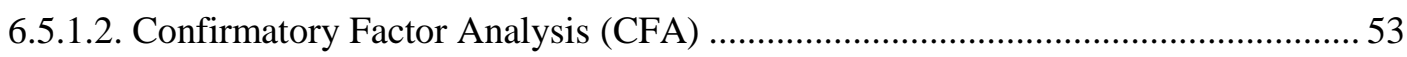

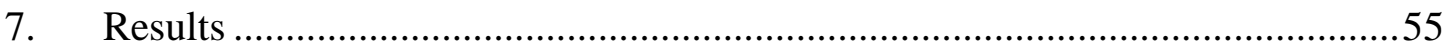

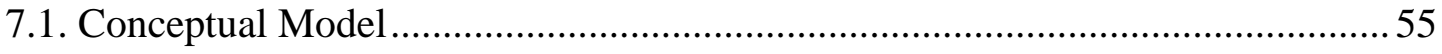

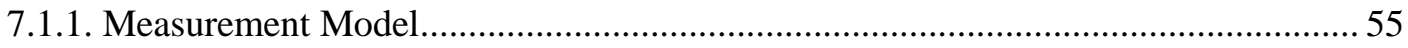

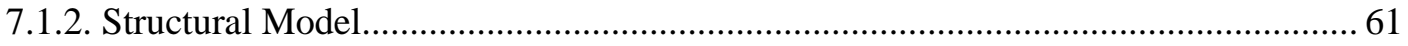

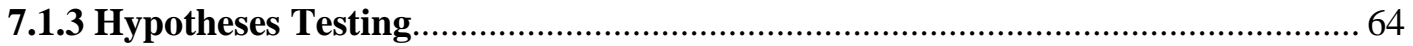

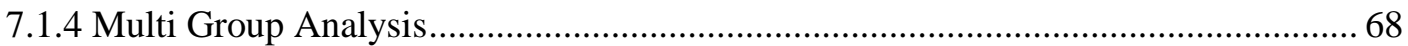

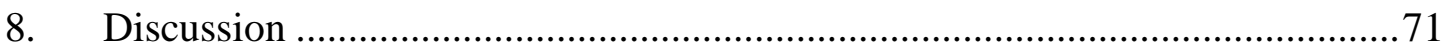

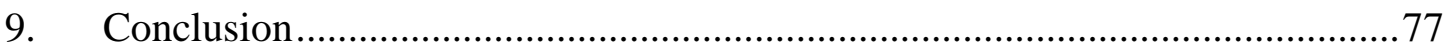

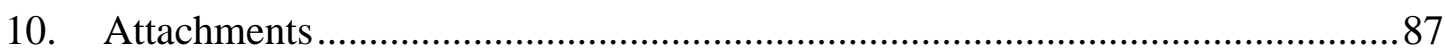

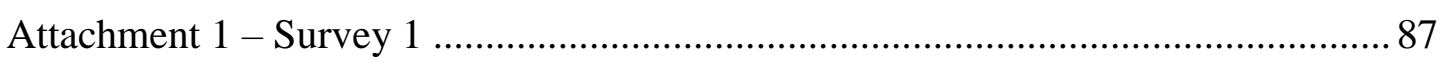

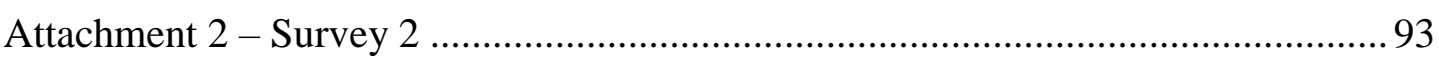




\section{Index of Tables}

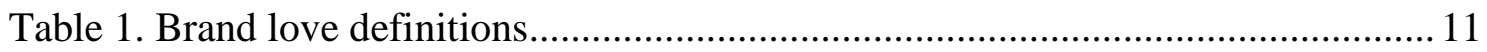

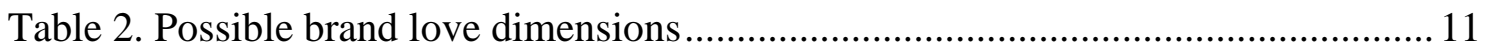

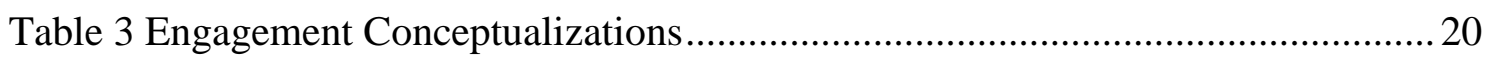

Table 4. Top 10 brands with more likes on Facebook - Fashion department ................ 25

Table 5. Brands' likes on Facebook Official Pages - Fashion department...................... 27

Table 6. Brands' likes on Instagram Official Pages - Fashion department .................... 28

Table 7. Top 12 brands with more likes on Facebook - Tech department....................29

Table 8. Brands' likes on Facebook Official Pages - Technological Department.......... 30

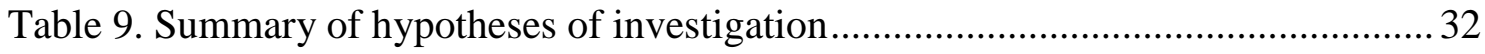

Table 10. Descriptive Statistics of the Latent Variables - study 1 ................................. 36

Table 11. Descriptive Statistics of the Latent Variables - study 2 ................................. 38

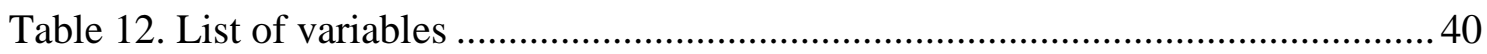

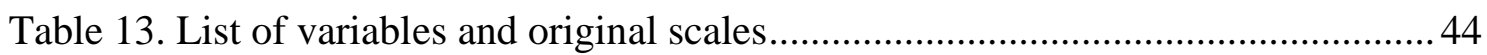

Table 14. Indexes of Reliability of the latent scales of the conceptual model ............... 45

Table 15. Indexes of Reliability of the latent scales of the conceptual model after

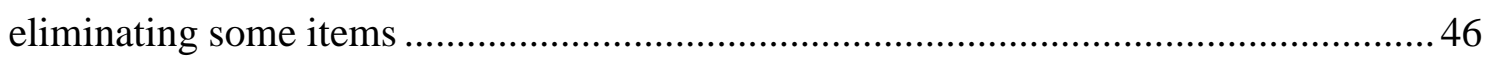

Table 16. Respondents per Brand - Study 1 ....................................................... 48

Table 17. Respondents per Brand - Study 2 ................................................. 49

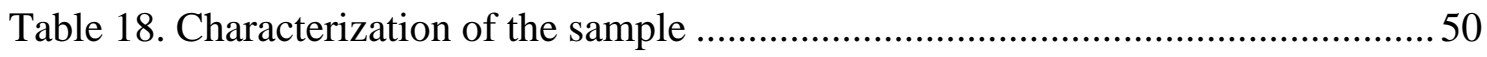

Table 19. Kaiser-Meyer-Olkin (KMO) and Bartlett Test of FPL, CEBSM, SIE, BL, EA,

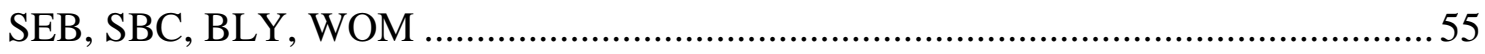

Table 20. Exploratory Factor Analysis - Principal Component Factor Analysis ........... 56 
Table 21. Construct Reliability (CR) and Average Variance Extracted (AVE) - own

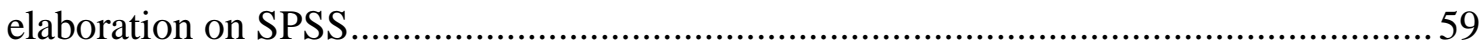

Table 22. Statistics and indexes of goodness of fit of the models .................................61 61

Table 23. Summary of hypotheses of investigation after SEM Analysis .......................65

Table 24. Standardized Total Effects (Direct + Indirect) .............................................6 66

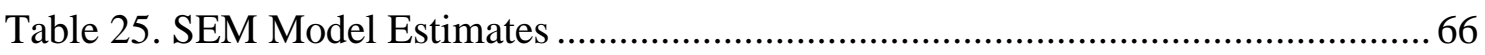

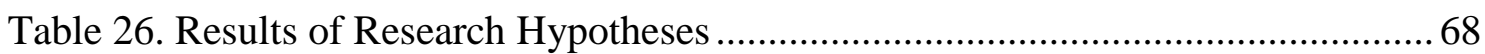




\section{Index of Figure}

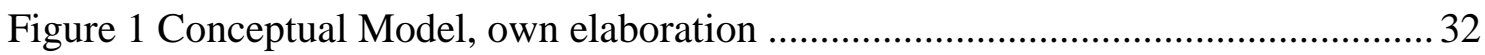

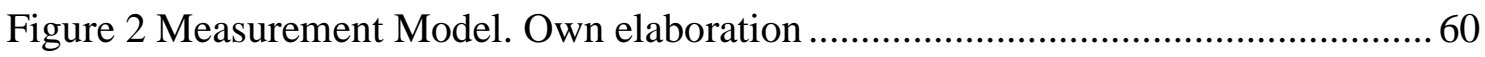

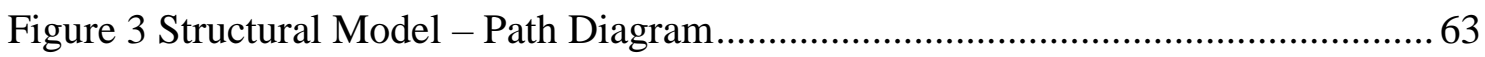






\section{List of Abbreviations}

AMOS - Analysis of Moment Structure

AVE - Average Variance Extracted

BL - Brand Love

CEBSM - Consumer Engagement Brand Related Social Media Content

CFA - Confirmatory Factor Analysis

CFI - Comparative Fit Index

CR - Composite Reliability

DF - Degree of Freedom

EA - Emotional Attachment

EFA - Exploratory Factor Analysis

KMO - Kaiser-Meyer-Olkin Test

NFI - Normed Fit Index

PCA - Principal Component Analysis

RMSEA - Root Mean Square Error of Approximation

SBC - Self-Brand Connections

SEB - Self-Expressive Brands

SEM - Structural Equation Modelling

SIE- Social Interactive Engagement

SPSS - Statistical Package for the Social Science

FPL - Fan Page Liking

WOM - Word of Mouth 


\section{Introduction}

Differentiate from competitors and offer distinguished products and experiences that apply to all consumers' senses is the purpose of every marketer and has becoming more difficult each day to achieve so.

Relying on Consumer Brand Relationships is viewed, in the following years, as a way to build, and keep, long-term relationships (Palmatier et al., 2013; Huber et al., 2015) as though as understanding consumers' needs and expectations.

The following chapter is composed by three sections (which the following introduction is excluded): the first presents the objective of the dissertation and the relevance for both academy and management purposes, the second explains the methodology and provisional investigation questions and the last serves as a brief explanation of the structure of this report.

The objective of this dissertation aims to explain and understand the impact of brand love in building brand loyalty among young consumers. The current topic was decided to be determinant to further investigation as, nowadays, in marketing strategy, it is important to comprehend why some consumers perceive distinguished characteristics towards a brand and not others. An investigation on Brand Love, as a potential antecedent of brand loyalty, is particular relevant to understand how commitment and attachment towards a brand turns into effective purchase behaviour and not only consider psychological determinants of purchase intention and attitudinal loyalty, that might be insufficient to predict the true impact of emotional brands on building brand loyalty.

As stated previously, concerning the modern society, consumer behaviour tends to be less predictable and more challenging to understand rather than on previous decades. It is then important to understand how to increase brand performance through an effective marketing strategy that might rely on emotional attachment over brands.

This particular topic has been studied on previous decades and perceived as more and more important for companies to retain and to build customer loyalty. With that in mind there are two determinants that have to be justified in order to understand this particular relevance: as the topic being relevant for the academy and to management purposes. 
For the academy we might highlight the hot topic that brand love and relationship marketing represent on current marketing strategies. Although there are several studies concerning the importance of corporate branding, investigation lacks of consensus regarding a established definition of brand love and/or brand emotion (Batra et al., 2012). It is important to understand that major research in this area focus on luxury brands and the emotional connection customers make with them result in a higher perception of their qualities and helps to establish premium prices (Hwang and Kandampully, 2012; So et al., 2013). However, scholars lack to explain if their findings have true results in purchase loyalty, meaning if that perception of brand love and attachment towards the brand represents true intention of buying and the intent to recommend it to others (Ahuvia, 2005). Investigation concerning the presence of customer-brand relationships in online communities is recent and insufficient and might offer potential (Moraes et al., 2014; Calefato et al., 2015; Huber et al., 2015; Sashittal et al., 2015; Vernuccio et al., 2015). Also, investigation concerning consumer-brand engagement would be of great relevance to better understand this constructs and the relationships we build with brands (Patterson, Yu and de Ruyter (2006); Vivek Beatty and Morgan (2010); Hollebeek (2011); Brodie et al.,2011).

Likewise, the drivers, that reflect brand loyalty through emotional brands, reunite no consensus among researchers, which might be interesting to predict and understand with this research. Therefore, it is perceived that true loyalty may require customers to form an emotional bond with the brand (Patwardhan and Balasubramanian, 2011).

As though for management purposes, and as stated before, it might be of no disagreement to state that marketing alone is no longer enough to influence purchase motivation and intention for consumers. Nowadays, consumers are exposed to several stimulus that interfere with their behavioural experience and are no longer sensible to only marketing and advertisement as we know it. With that in mind, it is of growing importance to seduce customers towards our brand, and emotional strategies might be of great relevant to achieve so. It is also known that consumers are keener to connect with a brand that responses with effective and emotional marketing and strategies. Also, consumers are more effective to establish commitment with a brand that reflects positive emotions and attitudes rather than only focusing on the physical attributes of the brand. 
Another important and relevant topic is that the millennium generation - considered by many as the golden consumer generation, as they will become the future adults and potential new consumers - hampers the concept of brand loyalty. Youngers are more willing to experiment different products and brands and lean more towards brands with whom they feel emotionally connected to.

To fulfil this limitations, this research work aims to understand how emotion appeals and, namely, having strong bonds with brands, can help to predict brand loyalty. Also, it is this research objective to understand if loved brands and social interactive engagement increase the willingness to buy those brands and maintain its loyalty. To answer this doubts were designed the following investigation questions that should be present in the current work and which are expected to offer relevant information and answers to branding purposes, namely, emotional branding: Is brand love effective in building true brand loyalty? Does interactive engagement with brands and brand love contribute to build brand loyalty? Does interactive engagement on social networks reflect millennials love of brands?

To better answer this objectives, we are going to analyse some key-factors about the evolvement and love for brands, and some constructs that might be correlated, namely, engagement constructs as Consumers' engagement with brand-related social-media content; Fan Page Liking and Social Interactive Engagement. Emotion constructs as Brand Attachment, Brand Love, Self-Expressive Brand and Self Brand Connection and the relation with Brand Loyalty and Word-of-Mouth.

Concerning this, is the aim of this research to try to combine constructs that have never been used before and offer new findings to the study of brand love, namely on social networks. The model used is of own elaboration and combines some of the more reliable and important constructs concerning the topic of analysis. Were considered the presence of brands on Facebook and Instagram and the object (the brands chosen) were extracted from Socialbakers concerning two different categories: Fashion and Electronics/Technology.

To study the following was conduct a quantitative methodology in the form of an online survey. The questionnaire was diffused on Facebook and by email to all students of Universidade do Porto and Nursering School of Porto. The survey was also sent to other 
Portuguese universities but we haven't obtained any response to the following. To gather data were conducted two different studies, covering Fashion and Technological brands as stated previously.

After collecting data, we analysed the following through Structural Equation Modelling (SEM). Next, we conducted a Multi-group factor analysis in order to understand if the perception of respondents considering the two surveys, was invariant.

Once we finished the analysis we evidenced that all the hypothesis we wanted to test were proved. Our findings suggested that every construct we correlated proved corrected, considering this investigation to be relevant. All hypothesis covered relation existing in the extant literature and other relations we wanted to investigate concerning some findings of the studies and papers that we investigated.

Finally, the structure of this investigation is the following: first we present some highlights concerning the topic of investigation in introduction, then we proceed to the literature revision where we will present some of our investigation concerning the topic of analysis, then we proceed with the chapter contemplating our methodology where will also be presented the hypothesis formulated, the conceptual model designed. Following, we continue with the results and findings of this investigation. At last, we will present a results discussion, a conclusion to this investigation, the bibliography used and the attachments area. 


\section{PART I. Literature Review}

\section{Introduction}

The topic of brand emotion is largely developed in literature from the past years. For decades, researchers have followed the idea that consumers might develop attitudes that reflect feelings of like or dislike towards brands (Batra et al., 2012). However, nowadays the concept of the existence of brand love (Carroll and Ahuvia, 2006) appears as a new construct to explain why some consumers might prefer some brands over others and the reason behind the existence of strong bonds with them.

This notion of consumer relationships is particular relevant in current society as advertising, as we know it, is no longer enough to attract or retain consumers to our brand and the products or service we provide. Because so, it appears to be crucial to develop new marketing strategies and Marketing Communication is an effective method to draw consumers' attention and bond relationships with them. Relationship Marketing is largely accepted as a marketing field effective on building strong relationships with consumers and, consequently, building loyalty. With that in mind, exploring the concept of Brand Love might be of greater relevance in building strong brands and settle long-term relationships with consumers.

Many finding suggest that satisfaction might play an important role in building emotional attachment towards certain brands (Carroll and Ahuvia, 2006). Brands that provide more hedonic features and symbolic benefits are seen as potentially more suitable to cause love romance with consumers.

The more a consumer is satisfied with our brand, chances are a better commitment he will develop with the brand. More positive WOM (Carroll and Ahuvia, 2006), stronger positive feelings towards brands and, consequently, greater consumer loyalty (Founier, 1998; Hwang and Kandampully, 2012) an increased willingness to pay a premium price (Thomson et al., 2005; Albert et al., 2013)a potential acceptance to forgive brand failures (Bauer, Heinrich and Albrecht, 2009 apud Batra et al., 2012) and resistance to negative information (Batra et al., 2012) are often seen (and proved) as irrepressible outcomes of an effective consumer-brand relationship (idem). 
The following section is divided in four different chapters with the first giving an highlight on consumer-brand relationship, the second exploring the concepts of brand emotion, with better focus on brand love, brand attachment and the new concept of brand passion, the third offers a brief description of brand loyalty as an outcome of brand emotion and last but not least, concerning the nature of this study, the former chapter explores the concept on engagement namely on social networks and by young consumers. 


\section{Consumer-brand relationship}

\subsection{Why consumers create bonds with brands}

The way people interact with brands has been largely studied practically since the concept of marketing has emerged as well the relationships built between the consumer and the brand.

But how can we define what a relationship is? Firstly, a relationship involves an interaction over time, composed of a "series of interactive episodes between dyadic parties" (Buttle, 2010). However, it is largely accepted that a relationship should include some type of affective connection, attachment or bond between the parties (ibidem) in order to be successful and considered like one.

People tend to be more attached and loyal to what they feel connected with (Bowlby, 1979 apud Hwang and Kandampully, 2012) and have the tendency to like people with whom they share common traits (Hwang and Kandampully, 2012: 99). This conclusion helps managers to acknowledge the growing importance of creating - and maintaining relationships with consumers in order to obtain brand success (ibidem).

It should also be considered that the existence of consumer-brand relationships helps to create more sustainable brands (Hwang and Kandampully, 2012) and enhances brand loyalty (C. W. Park et al., 2006), as an example. However, not all brands (or products) can be included, with the same degree, in this perception that a well-established relationship can result in commitment with their consumers. When the perceived risk [towards certain product or the field in which it performs] is higher, the role that brands hold in consumer's mind is bigger, which mean that commitment is greater in the purchase of durable goods (Kapferer, 2008).

To define consumer-brand relationship, we can search for roots in psychology as the concept does not differ too much on interpersonal relationships conceptualization. Concerning that consumer behaviour can be acknowledged as a psychological and social process people experience in the acquisition, use and disposal of products or services (Bagozzi et al., 2002 apud Kapferer, 2008). Though, consumer-brand feelings cannot be aligned with the way we interact with others, this kind of relationship can become more intense than simple liking (Carroll and Ahuvia, 2006). 
Trying to identify what builds a strong relationship with costumers, emotional aspects have been emphasized in growing literature (Patwardhan and Balasubramanian, 2011; Hwang and Kandampully, 2012; Albert et al., 2013). In the last decades, love has been notified as a common consumption-related emotion when relating with the use of certain products (Richins, 1997 apud Ahuvia, 2005). Brand Love (Carroll and Ahuvia, 2006) and Brand Attachment (C. W. Park et al., 2006) have commonly referred as constructs that might be able to explain the reason why a consumer chooses to connect with particular brands. This conceptualizations help, in their dimensions, to define what might increase and favourable successful relationships in a marketing context. Also, some researchers believe that improving brand reputation and brand satisfaction might also contribute to strengthen customer-brand relationships (Jurisic and Azevedo, 2011).

In the same dimension, the success of a relationship depends on the willingness of both parties to participate actively in it and the benefits both can extract from the relationship. Concerning that, and in view of the pleasure human beings obtain from "owning" a particular object, the idea that consumers can have love-like feelings for brands (Carroll and Ahuvia, 2006) come from the intense investigation on consumer-brand relationships (idem).

Although, not only consumers experience intrinsic benefits by establishing a relationship with a particular brand (whoever is a product or service brand). Companies, likewise, experience the requisite to establish ties with their consumers, since they can generate better results when they try to satisfy and retain some profitable customers (Buttle, 2010). Also, the cost of conquering a new customer is higher than retaining existing customers, resulting on companies seeing new customers' acquiring strategies as tactical: when the new customer offers future profit potential or concerning other strategic purposes (idem).

When taking into consideration the way consumers might feel when establishing a relationship, the intrinsic motivations of people should also be considered. The type of attachment we create with some objects (or particular brands) is considered to behave as a reflection of "mementos of key events or relationships in the life narrative" (Ahuvia, 2005: 179) turning them as an extent of consumers' identity, so it comes as no surprise that the way we feel about objects (and brands) might reflect the way we are as people (ibidem). 
People, commonly, use consumption as a way to establish their sense of personal identity and the way they interact with others (Ahuvia, 2005), so the importance of establishing true relationships and try to correspond to consumer's desires should not be neglected.

The love for particular objects can be both connected by the expression of the self [who we are as person and our preferences and impulses] and the realization of what we want to be (Ahuvia, 2005). Also, consumers often pick particular brands that might reflect consumers' personality. "We judge ourselves on certain choices" so that comes as a conclusion that our social identity is often built around the brands we wear (Kapferer, 2008: 20) or choose to buy. For that, brands are more likely to be seen as loved when they are connected with deeper constructs of consumer's personality, such as self-actualization, close interpersonal relationships (Richins, 1994 apud Batra et al., 2012), existential meaning, or religious and cultural identities (Batra et al., 2012).

In fact, concerning the point of love, people, when thinking about objects with whom they believe they shared any type of emotional attachment, listed that feeling [love] frequently, being only surpassed by happiness (Ahuvia, 2005). That can be explained largely because love often involves an integration between the brand and consumers' sense of identity (Carroll and Ahuvia, 2006). Consequently, the way love and emotion can influence brand relationships is going to be enlightened on the following chapter. 


\section{Brand emotion}

\subsection{Emotion constructs that better explain the existence of attachment toward brands and its antecedents and outcomes - Brand Love, Brand Attachment and Brand Passion}

"Consumers do fall truly, madly, deeply in love". Or at least, that's the belief of Brown (1998) in Patwardhan and Balasubramanian (2011 p. 298) research study.

The concept of emotional attachment, concerning brands and consumption, and the conviction that developing emotional bonds with brands predicts brand loyalty, or, at best, brand commitment, has attracted several researchers (Thomson et al., 2005; Carroll and Ahuvia, 2006; Albert et al., 2008, 2009; Patwardhan and Balasubramanian, 2011; Batra et al., 2012; Hwang and Kandampully, 2012; Albert and Merunka, 2013; Patwardhan and Balasubramanian, 2013; Huber et al., 2015) in the past years.

Concerning purchase goods, the very definition of love is long considered as a consumption-related emotion (Richins, 1997 apud Ahuvia, 2005: 171) although consumers tend to feel emotionally attached to a small subset of products of which they interact (Thomson et al., 2005; Huber et al., 2015). This means, that even though a consumer might purchase and experience a massive range of products during their lives, chances are they will only feel deep connections with a small amount of them. (Thomson et al., 2005) even though they might identify, or even commit, with a large range of them (Albert and Merunka, 2013).

Although establishing distinctive relation bonds with consumers has been massively accepted in past decades, not all brands are successful in doing so. Brand love is one of this constructs and, besides it is largely accepted as a relevant marketing topic and a management trend, little agreement exists on a current definition (Batra et al., 2012).

Brand love was first defined as "the degree of passionate emotional attachment a satisfied consumer has for a particular trade name" (Carroll and Ahuvia, 2006: 81). Although other authors might define it with different words, the definition frequently includes "passion for the brand, attachment to the brand, positive evaluation of the brand, positive emotions in response to the brand, and declarations of love for the brand" (ibidem). Despite the 
acknowledgment, today, the definition proposed by the previous authors is accepted as the main definition of the construct.

Table 1. Brand love definitions

Thomson et al. (2005) ～～[Brand Love] goes beyond brand attachment

Carroll and Ahuvia (2006) The degree of passionate emotional attachment a satisfied consumer has for a particular trade name. The definition includes: passion for the brand, attachment to the brand, positive evaluation of the brand, positive emotions in response to the brand, and declarations of love for the brand.

Batra et al. (2012) Considers several brand studies although they try to summarize it as a higher-order construct including multiple cognitions, emotions, and behaviors, which consumers organize into a mental prototype,

Albert et al. 2008

Considers the definition proposed by Carroll and Ahuvia, 2006

Source: Own elaboration

But even as brand love has emerged as an important construct to help develop strong relationships between brands and consumers, little is yet known about the antecedents of emotional feelings towards brands and even its behavioural consequences (outcomes) (Albert and Merunka, 2013) and even practical misinterpretation of what brand love is (Batra et al, 2012). Some authors believe that brand love has different conceptualizations, suggesting anywhere from 1 (Carroll and Ahuvia, 2006) to 11 dimensions (Albert et al., 2008).

Many researches have been trying to develop and propose dimensions which aim to better explain the concept of love applied to a consumer perspective.

Table 2. Possible brand love dimensions

\begin{tabular}{ll}
\hline Author(s) & Dimension(s) \\
\hline Fournier (1998) & Love and passion, \\
& Self-connection, \\
& Commitment, \\
& Inter-dependence, \\
\hline
\end{tabular}




\begin{tabular}{|c|c|}
\hline & $\begin{array}{l}\text { Intimacy and } \\
\text { Brand partner quality }\end{array}$ \\
\hline Thomson et al. (2005) & $\begin{array}{l}\text { First-order: } \\
\text { Passion, } \\
\text { Connection, } \\
\text { Affection } \\
\text { Second-order: } \\
\text { Emotional Attachment }\end{array}$ \\
\hline Carroll \& Ahuvia (2006) & Brand Love (with 10 items) \\
\hline Albert et al. (2008) & $\begin{array}{l}\text { Passion } \\
\text { Duration of the relationship } \\
\text { Self-congruity } \\
\text { Dreams } \\
\text { Memories } \\
\text { Pleasure } \\
\text { Attraction } \\
\text { Uniqueness } \\
\text { Beauty } \\
\text { Trust } \\
\text { Declaration of love }\end{array}$ \\
\hline Albert et al. (2009) & $\begin{array}{l}\text { First-order: } \\
\text { Idealisation, } \\
\text { Intimacy, } \\
\text { Pleasure, } \\
\text { Dream, } \\
\text { Memories, } \\
\text { Unicity } \\
\text { Second-order: } \\
\text { Passion, } \\
\text { Affection }\end{array}$ \\
\hline Batra et al. (2012) & $\begin{array}{l}\text { Enduring passion, } \\
\text { Self-brand integration, } \\
\text { Positive emotional connection, } \\
\text { Anticipated separation distress, } \\
\text { Long-term relationship (Loyalty/Commitment), } \\
\text { Overall attitude valence, } \\
\text { Attitude strength } 2 \text { (certainty/confidence) }\end{array}$ \\
\hline
\end{tabular}

Source: Own elaboration

Other authors propose different constructs concerning variables depending on interpersonal theories, which is the case of the interpersonal love theory - The triangular Theory of Love (Sternberg, 1986) - which was adapted to consumption contexts, regarding brand love, proposing three variables: passion, intimacy and commitment (e.g. 
Lastovicka and Sirianni, 2001; Shimp and Madden, 1998 apud Albert and Merunka, 2013). The Self-Expansion Model (Aron et al. 2001, 1998; Reimann and Aron, 2009 apud Patwardhan and Balasubramanian, 2011) has also been adapted to marketing concerning the subtopic of brand romance (Patwardhan and Balasubramanian, 2011) proposing brand romance as a three-factor (pleasure, arousal and dominance) construct. Albert and Merunka (2013) also offer a model that that attempts to identify new antecedents of brand love concerning brand trust and brand commitment, proving reliability and honesty as two brand trust variables that influence brand love. The authors' findings also include the positive influence of brand love in brand commitment, positive word-of-mouth and willingness to pay a premium price.

Brand attachment, on the other hand, is an emotional construct that tries to offer an understanding about why consumers might get emotional over a brand and have the willingness to maintain a relationship with it (Chaudhuri and Holbrook, 2001; C. W. Park et al., 2010; Albert and Merunka, 2013) although it is considered to establish a less stronger bond between brands and consumers than brand love itself. The conceptualization of brand attachment finds its roots on the Attachment Theory (Bowlby, 1979) which offers a perspective on "the degree to which individuals are strongly attached to a person" [or to a brand] defining their "level of commitment to the relationship and the level of acceptance of sacrifices involved in the relationship (Hwang and Kandampully, 2012).

Concerning that, attachment can be defined as a "emotion-laden target-specific bond between a person and a specific object" (Bowlby, 1979, 1980 apud Thomson et al., 2005: 78 ) and can also refer to the process of establishing emotional bonding (Collins and Read, 1990 apud Hwang and Kandampully, 2012) which, if develop through the consistent existence of experiences with a certain entity, like a person or brand, might increase the level of comfort in the relationship (Hwang and Kandampully, 2012)as consumers take comfort on what they find familiar as we often become more attached on the existence of feelings of security and safety (Patwardhan and Balasubramanian, 2011). As intense the connection with the object of attachment can be, eager the consumer will be on maintaining a connection and proximity with it. (Thomson et al., 2005). Regarding this information, Thomson et al. (2005) develop a three first-order factor scale, presenting 
Affection, Passion and Connection as its main dimensions, for measuring emotional attachment to brands.

However, besides emotional brand attachment is likely to depend on different constructs and variables that might differentiate consumers' perception to brands, all should reflect willingness to develop favourable feelings to a certain brand. For example, a consumer whose brand attachment is characterized as high in affection is more eager to give the brand as a gift to significant others (the affection towards the brand might represent the affection for the recipient). However, if the attachment is high in passion, the consumer would be keen to purchase the brand and even exceed the budget pre-defined due to the intense feelings certain brand might represent to them. On the contrary if the brand attachment is categorised as high in connection, the consumer might expend considerable effort to preserve the brand and even collect it (Thomson et al., 2005).

Likewise, based on brand love and brand attachment he can define the concept of brand passion, a term that has been highlighted by several authors in the following years (Albert et al., 2008, 2013; Zhong and Zhang, 2013; Swimberghe et al., 2014). For passion the literature considers a "state of intense longing for union with another" (Hatfield and Walster, 1978 apud Albert et al., 2013) within this passion process including physiological arousal and desired motivated by the longing to be with someone (Baumeister and Bratslavky, 1999 apud Albert et al., 2013). Considering human relationships, we define passion as an emotional state that people experience in the beginning of a relationship (Albert et al., 2013; Swimberghe et al., 2014) and that the intensity of feelings existent between the two parties vary (and consequently) decrease over time (Huber et al., 2015). Relying on this experience it is important to understand that relationship evolves and, thus, feelings change leading to a necessity on predicting customers' reactions and acceptance towards our brand (ibidem).

When a consumer feels passionate about a brand there is higher probabilities on developing intense feelings with it leading to the creation of a close relationship between the two parties (Albert et al., 2013). This kind of intense relationship is heightened by the constant presence of the brand in the passionate consumer's mind and the type of idealization he develops about it (Albert et al., 2008, 2013). 
Although other brand emotion's determinations have been recognized as predictors of brand engagement, brand passion is plausible to create a much more intense connection with brand loyalty, as brand passion may differ from impulse buying since desire usually involves feelings of longing, patience and sacrifice (Zhong and Zhang, 2013) leading to a much more deliberated thinking about the product or brand.

Passionate consumers are more likely to become good spreaders of the brand as they generate better (and more) positive word-of-mouth (Carroll and Ahuvia, 2006; Albert et al., 2013) along with the intention to communicate the benefits of the brand (Zhong and Zhang, 2013) although not all enthusiastic consumers are plausible, or willing, to talk positively about the brand or even try to convince others to use it (ibidem). However, if a consumer is passionate about a specific brand, it is plausible to engage in a much more emotional relationship with it or even develop feelings of absence when the brand is unavailable (Albert et al., 2013; Zhong and Zhang, 2013).

To sum up, there are several reasons of why a consumer might like (or not) a particular brand, although it is studied to be more connected to the possibly intrinsic rewards a brand might offer to a consumer (Batra et al., 2012) better than extrinsic benefits.

A loved brand might provide both benefits, although it is important to perceive that providing only extrinsic benefits to the consumer, will not translate into true emotional connection, though consumers might use the brand to get something else that they love (Batra et al, 2012). Not only is important to a consumer to identify themselves with a particular brand, but also develop empathy with other customers (Carroll and Ahuvia, 2006; Batra et al., 2012) even more when there is a fit between the consumer and other brand's enthusiasts, as other common customers, opinion leaders or even influential consumers (Albert and Merunka, 2013) that represent or identify themselves with the brand.

Companies are paying more attention in developing strategies that might not only retain, but also satisfy their customers. Although it is important to understand that brand love and satisfaction are completely different constructs (Carroll and Ahuvia, 2006) and do not rely on the same roots, as not all satisfied consumers might develop strong emotional feelings (i.e. Love) towards a brand (Carroll and Ahuvia, 2006). 
Brand love (Carroll and Ahuvia, 2006) refers to affective responses towards the brand, more than cognitive, which is more common on a satisfaction basis which might be the result of a long-term relationship with the brand. A consumer who experiences brand love is more willing to declare its feelings to the brand and that occurs because he recognizes the brand as an extension of its personality (Carroll and Ahuvia, 2006; Albert et al., 2009; Batra et al., 2012; Hwang and Kandampully, 2012; Albert et al., 2013; Swimberghe et al., 2014; Huber et al., 2015). Actually, the existence of feelings of love towards a brand is perceived in the literature (Rubin, 1970; Shimp and Madden, 1998 apud Huber et al., 2015 ) as the most intense emotion one can feel - concerning brands and human relations as we can easily relate.

However satisfaction has been considered as one of the main predictors of brand loyalty (Huber et al., 2015) a satisfied consumer is not necessarily a loyal one (ibidem) as a couple of circumstances might determinate what kind of product or brand a customer might switch to. Regarding the indefinition of potential antecedents and outcomes of brand loyalty and procedures a specific brand might opt to retain their customers, the following chapter aims to give a brief (and not yet fully extended) highlight on the concept of brand loyalty as an outcome of brand emotion. 


\section{Brand Loyalty}

\subsection{Understanding brand loyalty as a potential main outcome of brand love}

Although the potential antecedents of brand loyalty are not yet defined, some authors have been trying to respond to what might cause brand loyalty. From almost three decades now, brand loyalty is constantly recognized as a noteworthy contribute to marketing literature and management.

Brand loyalty can be defined as "conative loyalty" (Oliver, 1999 apud Carroll and Ahuvia, 2006: 82) or the disposition the consumer has to repurchase a particular brand (Carroll and Ahuvia, 2006).

Consumers who are seen as loyal, might be open to dispend a bigger amount of money to obtain the benefits from the brand they are committed with (Chaudhuri and Holbrook, 2001). That occurs because a retained customer is able to perceive unique values in the brand that no alternative is able to provide (Jacoby and Chestnut, 1978; Pessemier, 1959; Reichheld, 1996 apud Chaudhuri and Holbrook, 2001) such as trust in that brand (Chaudhuri and Holbrook, 2001) or the conceptualization of personal identification with that brand (Albert and Merunka, 2013).

When that specific characteristics are experienced, brands can see their performances arise, much to do with a potential increase of their market share and the ability to practice premium prices without disregarding massive advantages for marketing purposes as, just to mention some, reduced marketing costs, acquisition of new customers and greater trade leverage (Chaudhuri and Holbrook, 2001: 81). The increase of favourable word-of-mouth, the willingness to repurchase (Carroll and Ahuvia: 2006) and the resistance of retained customers to choose another alternative, are often considered as well.

Nowadays, people are more difficult to attract. They, spread their love through different directions and that includes brands. Retaining user relationships are now a reality because brands want to maintain loyal customers. Although, they are finding that this long-time relationship can no longer be achieved by simply creating a better product or service; they can be achieved by creating value as long-term buyers and this can be seen as valuable assets for companies (Nisar and Whitehead, 2016). 


\subsection{Attitudinal loyalty and Behavioural loyalty}

The concept of brand loyalty is being largely developed in the literature with companies and managers taking this concept as a strategy guideline. Brand loyalty, yet, involve a series of proportions that turns into a much more conceptualized dimension than we could figure at first.

Loyalty has been accepted as a two dimensional construct, including attitudinal and behavioural loyalty as its extents (Hwang and Kandampully: 2012).

When we talk about attitudinal loyalty we are referring to the disposition to establish some kind of commitment (or even the future purchase) with the brand (Chaudhuri and Holbrook, 2001). On the other hand, behavioural, or purchase loyalty, can be defined as the willingness to repurchase the same brand (Chaudhuri and Holbrook, 2001).

Attitudinal loyalty is mainly considered in previous research as it offers immediate evidence of how emotional aspects in consumer-brand relationships behave on influencing commitment, as their potential willingness to pay a premium price for a specific brand, for example (Hwang and Kandampully, 2012). Purchase loyalty, however, requires an actual purchase history, as it depends on the repurchase of the same brand. Still, that might be insufficient on predicting the bonds brands can create with their customers, as the repurchase might not occur due to consumer's inability to afford it (Bandyopadhyay and Martell, 2007 apud Hwang and Kandampully, 2012). 


\section{Consumer Engagement: how are we attracted to brands?}

\subsection{Young consumers and their relationship with brands}

It is of no surprise that young consumers visualize brands as parts of their self, creating real bonds with them. The way we feel about a specific brand might determinate the way they see themselves and how they believe others see them.

The social self is becoming an increasing part of the self, with the online "me" becoming more important each day for young consumers than the true self. Creating an identity online is more important each day, with millennials valuing more and more the way they behave online and how others behave. Interacting with others and being available all the time through all social media platforms is almost mandatory and anyone that acts differently is seen an outsider.

Concerning about the way society views us is of great importance for young consumers in a way it never happened to anterior generations. Everything we post, like or comment is immediately object of analyses of someone, so the online behaviour people adopt is less than casual.

This trend has evolved through the way consumers communicate and percept brands. Consumers now value social media and trust if as a communication medium far more than traditional media (Nisar and Whitehead, 2016). Concerning this point more and more brands are adopting a relevant online identity to attract and create valuable relationships with their consumers (idem). Having an online, particularly, a social media identity helps brands to increase brand awareness and brand recognition with their consumers that can improve the relationship brands have with their consumers.

Accordingly to Baird and Parasnis (2011) $23 \%$ of people consider the interaction with brands on social media as a reason to use the social platforms so it comes a great advance to brands to connect with their "fans" (Kudeshia et al., 2016) through social media. Also, SM offers new possibilities trying to understand what customers are interested in and then use this information to attract and retain them. (Chen, Lu, Wang, Zhao and Li, 2013, Choi \& Bazarova, 2015 apud Nisar and Whitehead, 2016). Some also use this information to adapt their offer to what their consumer really want (ibidem). 


\subsection{Engagement}

The definitions of engagement are developing in the current world. Although the concept isn't new in the management area, the concept has been evolving and developing in the last decade (Brodie et al., 2011).

Despite the growing popularity of the term "engagement" few authors have attempted to define the concept. (Brodie et al., 2011)

In studies published to date, engagement is defined as a combination of cognitive aspects, behavioural aspects and/or emotional aspects (Dijkmans et al., 2015). Also, Calder et al., 2009 proposed engagement as higher-level measurement of consumers' relationship with the surrounding media context compared to experience measures. Below, there are presented some engagement conceptualizations described by Brodie et al., 2011).

Table 3 Engagement Conceptualizations

\begin{tabular}{|c|c|c|}
\hline $\begin{array}{l}\text { Patterson et al. } \\
\text { (2006) }\end{array}$ & $\begin{array}{l}\text { Customer } \\
\text { Engagement }\end{array}$ & $\begin{array}{l}\text { The level of a customer's physical, cognitive } \\
\text { and emotional presence in their relationship } \\
\text { with a service organisation. }\end{array}$ \\
\hline $\begin{array}{l}\text { Vivek, Beatty and } \\
\text { Morgan (2010) }\end{array}$ & $\begin{array}{l}\text { Consumer } \\
\text { Engagement }\end{array}$ & $\begin{array}{l}\text { The intensity of an individual's participation } \\
\text { and connection with the organization's offerings } \\
\text { and activities initiated by either the customer or } \\
\text { the organization. }\end{array}$ \\
\hline $\begin{array}{l}\text { Mollen and Wilson } \\
\text { (2010) }\end{array}$ & $\begin{array}{l}\text { Online brand } \\
\text { engagement }\end{array}$ & $\begin{array}{l}\text { The customer's cognitive and affective } \\
\text { commitment to an active relationship with the } \\
\text { brand as personified by the website or other } \\
\text { computer-mediated entities designed to } \\
\text { communicate brand value. }\end{array}$ \\
\hline Van Doorn et al. & $\begin{array}{l}\text { Customer } \\
\text { engagement } \\
\text { behaviour }\end{array}$ & $\begin{array}{l}\text { Customers' behavioural manifestation toward a } \\
\text { brand or firm, beyond purchase, resulting from } \\
\text { motivational drivers such as word-of-mouth } \\
\text { activity, recommendations, helping other } \\
\text { customers, blogging, writing reviews. }\end{array}$ \\
\hline Hollebeek (2011) & $\begin{array}{l}\text { Customer brand } \\
\text { engagement }\end{array}$ & $\begin{array}{l}\text { The level of a customer's motivational, brand- } \\
\text { related and context-dependent state of mind } \\
\text { characterized by specific levels of cognitive, } \\
\text { emotional and behavioural activity in brand } \\
\text { interactions. }\end{array}$ \\
\hline $\begin{array}{l}\text { Higgins and Scholer } \\
\text { (2009) }\end{array}$ & Engagement & $\begin{array}{l}\text { A state of being involved, occupied, fully } \\
\text { absorbed or engrossed in something, generating } \\
\text { consequences of a particular attraction or } \\
\text { repulsion force. The more engaged individuals }\end{array}$ \\
\hline
\end{tabular}


are to approach or repel a target, the more value

is added to or subtracted from it.

Source: adapted from Brodie et al., 2011

Also, Calder et al. (2009) identified two types of engagement, namely personal engagement and social interactive engagement. Personal engagement means users seek stimulation and inspiration and are prone to talk about content with others feeling the website (or social network) as extension of their own (Calder et al., 2009; Vernuccio et $a l ., 2015)$. On the contrary, social interactive engagement is a way for people to obtain more value by socializing and participating in the social network and receive input from others experience (ibidem).

The interactive nature of social media ultimately has changed how consumers engage with brands. (Schivinski et al., 2016). When using social media on a regular basis, consumers come into contact with myriad brands and products by reading, writing, watching, commenting, "Liking," sharing, and so forth (ibidem). Boundaries were defined according to the level of consumer engagement with user-generated media and suggested that people engage with such media in three ways (Shao, 2009 apud Schivinsky et al., 2016)): by consuming, by participating and by producing brand-related media.

Social Media have changed the way we interact with others and with companies, namely brands (Hanna, Rohm and Crittenden, 2011; Kietzmann, Hermkens, McCarthy and Silvestre, 2011 apud Dijkmans et al., 2015). Online network-based communities stimulate various dimensions of consumer engagement. (Hollebeek et al., 2014; Vernuccio et al., 2015). Also, social media platforms like Facebook and Twitter provide a substantive part of the available online word-of-mouth. (Dijkmans et al., 2015).

The proliferation of social media use among companies has raised questions about the effect of their social media efforts. (Dijkmans et al., 2015) leading to the necessity of exploring this relations in order to obtain the best for them. Since young consumers are more difficult to conquer, trying to seduce them through social media might be a way to achieve so. Nowadays, more and more brands are attracting young consumers by their social networks, creating and maintaining content that attracts them truly. 
With this in consideration, social consumer engagement needs to be taken more seriously into account, concerning its representation in online communities. (Vernuccio et al., 2015)

Wallace et al, (2012) also emphasizes that the consumers like of a brand is an expression of his love for the brand and is idea of a self. (Ahuvia, 2005). Actually, In online communities it is considered as a certain expression of brand love and positive emotional consumer-brand relationships, the "Like" button (Vernuccio et al., 2015). Pursuing this, Facebook launched in 2007 the Fan Pages. This fan pages allows consumers to affiliate with their favourite brands and to interact with others (Kudeshia et al., 2016).

When a consumer likes a page, he is proving that he is a fan of that brand to everyone. That allows brands to use this pages as business communication tools in order to establish connection with their consumers (Kudeshia et al., 2016) and trying to attract them while offering what they need. Also, it is believed that when an individual is connected with a brand through social networks are prone to build brand dedication and additionally contribute with positive WOM (Swanni et al., 2013 apud Kudeshia et al., 2016).

When relationships are strong and we build consumer-brand emotional bonds we can talk about evidence of brand loyalty and willingness to pay premium prices (Grisaffe and Nguyen, 2011; Malar et al., 2011; Park et al., 2010; Thomson et al., 2005 apud Vernuccio et al., 2015). 


\section{Part II Empirical study}

\section{Methodology}

Based on the literature review presented before, the following chapter will present the aim of this investigation, the object of study, the conceptual model that sustains the study and the hypothesis that were considered.

In this chapter, will also be presented the structure of the survey conducted and the variables chosen to construct it as long as the data collected and its results. Last but not least, will be presented some methodological considerations about the Structural Equation Modelling Model.

For the data analysis and development of the current project were used SPSS 24 and AMOS 24 softwares.

\subsection{Research objectives}

This research has a main goal understand the impact of brand love with young consumers. To answer that, and as presented earlier, this research aims to answer the following questions:

1. Is brand love effective in building true brand loyalty?

2. Does interactive engagement with brands and brand love contribute to build brand loyalty?

3. Does interactive engagement on social networks reflect millennials love of brands?

The following chapters will provide important findings to try to answer these questions. All the results will be explained and listed at chapter 6 and the discussion of the results will be described at chapter 7 .

\subsection{Study objects - Loved Brands}

The field of study of this research are brands that are beloved for most part of the consumers. Only with that characteristic would be able to understand, and predict, brands 
that are mostly susceptible to gather Brand Love or having consumers express any kind of brand emotion towards them.

Concerning that, were analysed two internet pages specialized in gathering information for social networks, namely fan likes, FanPageList.com and SocialBakers.com ${ }^{1}$

Social Bakers is one of the largest platforms on the internet covering statistics about brands on social media. The platform is a member of Facebook Marketing Partners and "serves over 2500 clients across 100 countries", as stated on the company's official website. It is the company's mission to "analyse and benchmark over 8 million social profiles" across all the major and relevant social media.

As Social Bakers had more accurate and recent data, and a sector division that has believed to make more sense, were selected two different sections: one covering Fashion ${ }^{2}$ and another one covering Technology and Electronic Goods.

Most part of the brands covered in this range are also part of the top 100 best brands selected by Interbrand. Interbrand is one of the most credible brand consultant enterprises in the world and, every year, conducts a TOP 100 of the most valuable brands in the world.

The selection of these categories of brands relied basically on millennials preferences, which go mostly beyond technology, to beauty and fashion.

\subsubsection{Study 1}

As literature presents a gap in fast consumer goods it comes as great relevance to try to explain and study how brands in the fashion world attract consumers. There are some studies covering consumer goods, but most part of them try to focus on luxury brands

\footnotetext{
${ }^{1}$ http://www.socialbakers.com/

${ }^{2}$ http://www.socialbakers.com/statistics/facebook/pages/total/brands/fashion/ researched on 25 june of 2016
} 
with, due to their high prices, status and exclusivity are also more susceptible to conduct to love of brands and interaction.

However, the literature lack to explain if fast and more accessible consumer goods also can lead to brand emotion. Also, millennials have different interests from earlier generations concerning consumption goods.

However, this topic is particular relevant as, nowadays, millennials are more and more concerned about the way they see themselves and expect others to see them. Sites regarding fashion trends and fashion products have more enthusiasts and fans than ever. Dressing in a certain way is more relevant each day

The following list presents an interesting range of brands selected by Social Bakers as the top 10 brands concerning Facebook Fanwood - as meaning as brands that gather more likes on social networks.

\section{Table 4. Top 10 brands with more likes on Facebook - Fashion department}

$\begin{array}{ll}\text { 1. } & \text { Converse } \\ \text { 2. } & \text { Adidas Originals } \\ \text { 3. } & \text { H\&M } \\ \text { 4. } & \text { Victoria's Secret } \\ \text { 5. } & \text { Zara } \\ 6 . & \text { Levi's } \\ \text { 7. } & \text { Louis Vuitton } \\ \text { 8. } & \text { Burberry } \\ 9 . & \text { Michael Kors } \\ \text { 10. } & \text { Chanel }\end{array}$

Source: Own elaboration based on SocialBakers.com information list

The information concerning fan page liking, is particularly interesting as, since the launch of "Fan Pages" in 2007, brands have been presented to a whole new form on contacting and interacting with their fans (Kudeshia et al., 2016). On Facebook, brands have the opportunity to send messages "to a huge number of fans" (Kudeshia et al., 2016: 258) 
while giving customers the chance to connect with their favourite brands, recommend it on their profile pages (idem) and be part of the community.

Liking a brand is shared by many authors (Ahuvia, 2005; Vernuccio et al., 2015) as an expression of real feelings towards a brand, but mostly as an expression of the inner self and the inside inspirations. Liking a page allows the potential (or actual) consumers to connect with brands as well as it improves the ability to create and expands its social side (Vernuccio et al., 2015).

Although brands acknowledge the importance of using social networks, specifically Facebook, as an important, interesting and cheap tool to communicate and interact with consumers, its effects on consumer behaviour is yet to be completely understood ((Kudeshia et al., 2016).

Many studies have tried to study and explain the effects on brands using social networks to communicate with their customers or even motivations on using it. Consumers now value social media as a way to communicate and be informed in ways that were never expected before (Nisar and Whitehead, 2016).

Some have tried to study and understand the outcomes about using it, but the literature has a lack of information concerning the point. Trying to connect this research with brand love and brand loyalty comes a particular new topic, so exploring social networks offers great potential to the current study. Also consumers spend more and more time on social networks nowadays, which offers potential to help reinforcing and increase brand awareness among them. (Nisar and Whitehead, 2016).

Following, it is presented a table that shows the relevance on Facebook accomplished by the brands presented below, ranked according to the Social Bakers top and by likes, which shows that the analyses of the site is accurate. 
Table 5. Brands' likes on Facebook Official Pages - Fashion department ${ }^{3}$

$\begin{array}{cc}\text { Brands } & \text { Facebook Fans } \\ \text { Converse } & 43.654 .508 \\ \text { Adidas Originals } & 31.122 .692 \\ \text { H\&M } & 32.081 .711 \\ \text { Victoria's Secret } & 28.473 .550 \\ \text { Zara } & 25.826 .143 \\ \text { Levi's } & 24.894655 \\ \text { Louis Vuitton } & 20.455 .723 \\ \text { Burberry } & 17.274 .044 \\ \text { Michael Kors } & 17.265 .965 \\ \text { Chanel } & 20.045 .303 \\ & \text { Source: Own elaboration with Facebook data }\end{array}$

Also, was chosen to include information concerning brands activity on Instagram, a fastraising social networks with more than 500 million followers worldwide, concerning Instagram official blog. ${ }^{4}$

Instagram has been accomplished an important place on social media and brands recognized its value leading them to the social network that speaks with pictures.

There, brands face a new challenge and some brands are doing best than others, it all depends on the strategy.

Besides being the best positioned brand on Facebook concerning the Fashion segment, Converse has a significantly low presence on Instagram when compared to the other 10 brands. Victoria's Secret has the best performance much concerning the fact that the lingerie and fashion-beauty segments communicate a lot with images. Though it is this research aim also to identify the type of target of this brands with their presence on social media, especially concerning this two social networks.

\footnotetext{
${ }^{3}$ Information last updated at $14^{\text {th }}$ september of 2017

${ }^{4}$ http://blog.instagram.com/post/146255204757/160621-news consulted on 29th of june 2016
} 
Table 6. Brands' likes on Instagram Official Pages - Fashion department ${ }^{5}$

\begin{tabular}{|cc} 
Brands & Instagram Fans \\
Converse & 6.244 .214 \\
Adidas Originals & 22.246 .213 \\
H\&M & 22.819 .628 \\
Victoria's Secret & 57.016 .834 \\
Zara & 22.102 .012 \\
Levi's & 2.634 .952 \\
Louis Vuitton & 19.003 .151 \\
Burberry & 10.028 .997 \\
Michael Kors & 10.504 .419 \\
Chanel & 23.986 .289 \\
& Source: Own elaboration with Instagram data
\end{tabular}

Although Twitter is one of the largest and relevant social networks in the world, was thought to not include a research on this as this study is based on Portugal and, as the universe covers mostly Portuguese students and millennials, this social network is not particularly significant in the country so it offers little importance to the study that it is being presented.

\subsubsection{Study 2}

After conducting and gather data from the previous study, we first analysed the data shortly.

It began to be necessary to explore this data a bit more in order to really gather data that would represent a great part of millennials. Although, nowadays fashion sector is of great importance to most part of millennials, a brief look to the data revealed that most part of the inquiries were girls. With that in mind, we run again to Social Bakers to extract

${ }^{5}$ Information last updated at $14^{\text {th }}$ september of 2017 
information of relevant brands in social media concerning the topics of "electronics and services" and use them to create a new group of brands that we have called "technology". Millennials are known about their interest in everything technological and internet. So, all the big players in tech today and in online services are among one of the most relevant and hot topics In millennials generation. The "have you seen the new Apple launch" or "what about that new Samsung phone? It looks incredible" are currently in their daily conversations and concerns. Everyone wants to have the most brand new technology just to have social position.

The current Apple fever that has been rising in the following years is a mirror of this obsession with technology and loved tech brands. So, considering this, we wanted to test a model that contemplate also this type of brands. In this study, Apple was not considered as an option since they don't have any official page on the social networks we are analysing. The brand is only present at Twitter.

Bellow it is considered, at table 6, the next pool of brands that we have selected.

Table 7. Top 12 brands with more likes on Facebook - Tech department

1. Huawei

2. Microsoft Lumia

3. Samsung

4. Intel

5. Playstation

6. Blackberry

7. Asus

8. Sony

9. Netflix

10. Itunes

11. Amazon

12. Spotify

Source: Own elaboration based on SocialBakers.com information list Equally, to the first study presented earlier it is also show the amount of followers these brands have on Facebook and also on Instagram. 
Table 8. Brands' likes on Facebook Official Pages - Technological Department ${ }^{6}$

$\begin{array}{ccc}\text { Brands } & \text { Facebook Fans } & \text { Instagram Fans } \\ \text { Huawei } & 46.797 .805 & 449.948 \\ \text { Microsoft Lumia } & 45.572 .872 & 320.867 \\ \text { Samsung } & 43.263 .719 & 3.700 .564 \\ \text { Intel } & 38.636 .533 & 1.021 .698 \\ \text { Playstation } & 38.403 .343 & 8.760 .558 \\ \text { Blackberry } & 26.918 .743 & 187.551 \\ \text { Asus } & 25.152 .729 & 428.344 \\ \text { Sony } & 7.697 .544 & 4.728 .397 \\ \text { Netflix } & 38.921 .033 & 4.627 .989 \\ \text { Itunes } & 30.785 .688 & 1.273 .159 \\ \text { Amazon } & 27.872 .907 & 1.022 .127 \\ \text { Spotify } & 17.448 .331 & 1.343 .289 \\ & \text { Source: Own elaboration with Facebook and Instagram data }\end{array}$

With the information provided above, we can understand that opting to conduct a second survey became of great relevance for this study. Concerning the acceptance of the technological brands in this two social networks - Facebook and Instagram - we can easily assume that this type of brands may attract a significant number of users.

In the following chapter is going to be presented the conceptual model designed to this research, as well as the variables chosen and adapted that best accompany the objective of this research, and the formulation of the hypothesis this investigation aims to correlate.

\subsection{Conceptual framework and hypothesis formulation}

A conceptual model or framework comes of great relevance to the topic of this research. It is this dissertation aim to discuss the following objective: understand how emotion appeals and, namely, having strong bonds with brands, can help to predict brand loyalty, understand if loved brands and social interactive engagement increase the willingness to

\footnotetext{
${ }^{6}$ Information last updated at $14^{\text {th }}$ september of 2017
} 
buy those brands and maintain its loyalty and if the presence we do on social networks reflect love of brands.

To correctly answer this objective and aim, were formulated the questions presented below, which this study, and the conceptual framework designed, aim to provide answers: Is brand love effective in building true brand loyalty? Does interactive engagement with brands and brand love contribute to build brand loyalty? Does consumer and interactive engagement on social networks reflect millennials love of brands?

Although the purpose is exigent, we truly believed that the framework presented in image 1 bellow, correctly and efficiently will provide the answers to this doubts. Although, as the formulation of the questions presented above can offer various subtopics and specifications the following objectives were designed to better delimitate the purpose of this research:

1. Understand what kind of feeling consumers establish with brands;

2. Understand if following a brand on social networks is directly associated with feelings of love towards a brand;

3. Understand and predict if a consumer "liking" a page on social networks and social engaging it has effects on their brand loyalty;

4. Understand if "liking a page" and interacting with it on social networks increase brand loyalty and willingness to buy;

5. Understand if a consumer in love is more willing to talk about a specific brand and recommend it to others;

6. Offer and suggest a conceptual model that links brand love and interactive engagement (or social engagement) with brand loyalty.

Taking this into consideration, below it is presented a conceptual framework for this investigation, based on several literature concerning the topic to brand love, brand loyalty and engagement on social networks. 


\section{Figure 1 Conceptual Model, own elaboration}

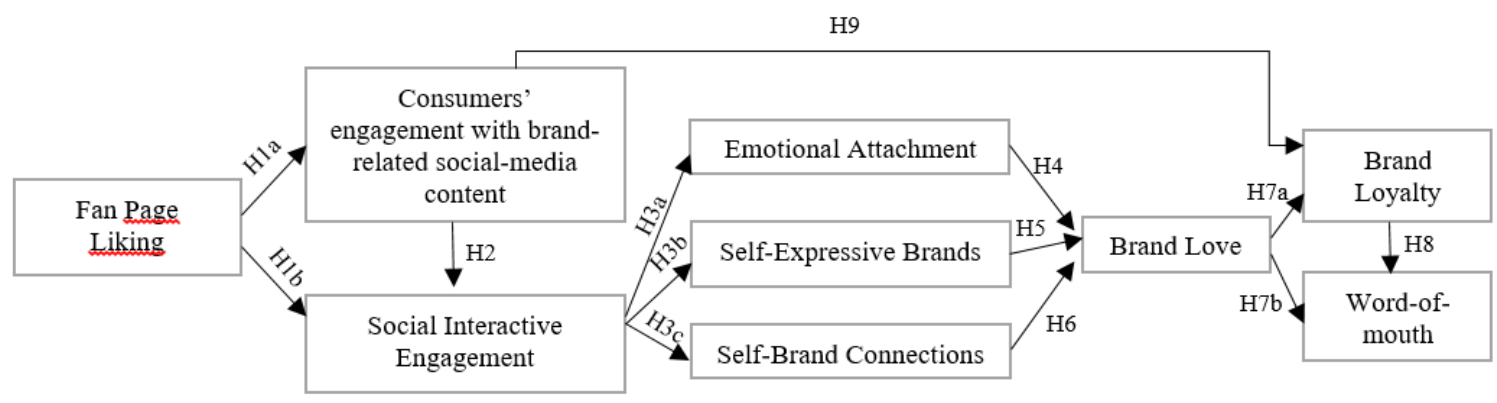

Source: Own elaboration

The model presented above in figure 1 tries to answer the relationship between important variables to the aim of this research - the major part are important variables in literature diffusedly used and understand as relevant to any marketing emotion-related study - as well as the investigation hypotheses formulated. This conceptual model tries to give answers to the questions presented earlier: (1) Is brand love effective in building true brand loyalty? (2) Does interactive engagement with brands and brand love contribute to build brand loyalty? (2) Does consumer and interactive engagement on social networks reflect millennials love of brands?

The following table (table 8) presents the investigation hypotheses formulated:

\section{Table 9. Summary of hypotheses of investigation}

H1a. Fan Page Liking has a positive direct impact on Consumers' engagement with brandrelated social-media content.

H1b. Fan Page Liking has a positive direct impact on Social Interactive Engagement

H2. Consumers' engagement with brand-related social-media content has a positive direct impact on Social Interactive Engagement.

H3a. Social Interactive Engagement has a positive direct impact on Emotional Attachment.

H3b. Social Interactive Engagement has a positive direct impact on Self-Expressive Brands.

H3c. Social Interactive Engagement has a positive direct impact on Self-Brand Connections.

H4. Emotional Attachment has a positive direct impact on Brand Love.

H5. Self-Expressive Brands has a positive direct impact on Brand Love. 
H6. Self-Brand Connections has a positive direct impact on Brand Love.

H7a. Brand Love has positive impact on Brand Loyalty.

H7b. Brand Love has positive impact on WOM.

H8. Brand Loyalty has positive impact on WOM.

H9. Consumers' engagement with brand-related social-media content has a positive direct impact on Brand Loyalty.

Source: Own elaboration

\subsection{Methodological Considerations}

Nowadays, conduction a survey is particularly easy since the evolution of internet. Online Marketing Research, covering email, to webpages and surveys, for instance, is increasingly being used by several academics worldwide.

In a short amount of time and with low investment, it is possible due to this technique to gather a significate and numerous answers in a short amount of time.

On the other hand, impaired objectivity is a pointed disadvantage to this method. However, surveys arethe most common technique for collecting data, in an investigatory context so, for this particular study was applied the same logic and the most effective and faster way to collect primary data.

In this survey, each respondent were asked to answer to the same questions as the entire sample. Although the questions were the same for every respondent, the object (a loved brand) were different for every respondent and the answers would reflect their feelings and experiences with that particular brand. Exception made to a question to filter the audience (Do you have any social network) and one question to select if they followed the chosen brand on Facebook and Instagram. The ones who didn't, haven't responded the questions concerning interactive experiences.

\subsubsection{Survey structure and data variables}

To better answer the present study were taken into consideration, not only the object of the study, but also the recipients of the following and the evolvement of technology. 
To do so, was selected a quantitative methodology with the non-documental technique of indirect observation in the form of an online survey, as presented earlier.

This technique is particularly relevant and massively used concerning its low budget investment, the fastness to diffuse it with other inquiries in a short amount of time it takes to gather relevant and numerous data.

\section{The questionnaire - structure}

The survey was preceded of a small explaining text, shared by email and on social media - was used the social network Facebook.

The inquiries were informed that the objective of the following survey was to analyse and comprehend their relationship with the brands exposed on the survey but were not told that was being analysed their level of brand love, brand loyalty and engagement towards the chosen brand in order for them to not feel tempt to skew the answers.

The inquiries were told to select a brand they most like - of the preview list of brands above exposed - without considering their value or ability to buy it, just the personal taste.

All the questions presented on que survey were closed and mandatory, although there were plenty of paths during the survey, concerning the previous answers. For example, someone who have stated that they have no social network account would be directed to the end of the survey as it is based on interaction with brands in social media. The ones who didn't follow the chosen brand on Facebook or Instagram would be conducted to the answers not covering interactive experiences on social media.

The end of the survey tried to understand the profile of the inquiry, through questions considering, age, gender, education and occupation.

\section{Variable Scales}

To answer the formulated hypothesis were adapted the following variables extracted for other studies that concern the topic of analysis and are recurrent in literature as great variables of study. It was decided not to adapt set of variables from another study because there were none that presented all the variables we wanted to study.

Nevertheless, some variables were extracted for the most credible and largely adapted studies and all presented and discussed at the literature revision presented before. 
Considering that the literature revision might to be sufficient to correlate new or adapted variables, the following were chosen not to be adapted but presented as in the original studies. The innovation comes with the non-seen use of the variables together in one project.

There are eleven variables based on literature review exposed earlier and concerning the topic of analysis. They were also used in the conceptual model: (1) Fan Page Liking; (2) Consumers' Engagement with Brand Related Social Media Content (Consumption and Contribution); (3) Social-Interactive Engagement; (4) Brand Love; (5) Emotional Attachment; (6) Self-Expressive Brands; (7) Self-Brand Connections; (8) Brand Loyalty; (9) Word-of-Mouth.

Below, at table 9 are presented the descriptive statistic of the latent variables for each study conducted, 1 and 2, correspondently. 
Table 10. Descriptive Statistics of the Latent Variables - study 1

\begin{tabular}{|c|c|c|c|c|}
\hline & Mean & Median & Mode & $\begin{array}{l}\text { Standard } \\
\text { Deviation }\end{array}$ \\
\hline \multicolumn{5}{|c|}{ Fan Page Liking } \\
\hline FPL1 & 4,61 & 5,00 & 5 & 1,474 \\
\hline FPL2 & 3,05 & 3,00 & 2 & 1,598 \\
\hline FPL3 & 1,69 & 1,00 & 1 & 1,293 \\
\hline FPL4 & 5,77 & 6,00 & 7 & 1,352 \\
\hline FPL5 & 3,19 & 3,00 & 1 & 1,803 \\
\hline FPL6 & 1,98 & 1,00 & 1 & 1,456 \\
\hline \multicolumn{5}{|c|}{ Consumers' Engagement with Brand } \\
\hline \multicolumn{5}{|c|}{ Related Social Media Content } \\
\hline \multicolumn{5}{|c|}{ Consumption } \\
\hline CONS1 & 4,30 & 4,00 & 5 & 1,747 \\
\hline CONS2 & 2,18 & 1,00 & 1 & 1,593 \\
\hline CONS3 & 3,74 & 4,00 & 1 & 2,015 \\
\hline CONS4 & 2,35 & 2,00 & 1 & 1,664 \\
\hline \multicolumn{5}{|c|}{ Contribution } \\
\hline CONTR1 & 1,70 & 1,00 & 1 & 1,155 \\
\hline CONTR2 & 1,75 & 1,00 & 1 & 1,195 \\
\hline CONTR3 & 1,76 & 1,00 & 1 & 1,239 \\
\hline CONTR4 & 2,24 & 2,00 & 1 & 1,547 \\
\hline CONTR5 & 4,46 & 5,00 & 6 & 1,875 \\
\hline CONTR6 & 4,39 & 5,00 & 6 & 1,836 \\
\hline \multicolumn{5}{|c|}{ Social-Interactive Engagement } \\
\hline SIE1 & 1,78 & 1,00 & 1 & 1,288 \\
\hline SIE2 & 1,45 & 1,00 & 1 &, 834 \\
\hline SIE3 & 2,12 & 1,00 & 1 & 1,480 \\
\hline SIE4 & 1,95 & 1,00 & 1 & 1,346 \\
\hline SIE5 & 3,30 & 3,00 & 4 & 1,534 \\
\hline SIE6 & 1,70 & 1,00 & 1 & 1,167 \\
\hline SIE7 & 1,88 & 1,00 & 1 & 1,317 \\
\hline SIE8 & 2,26 & 2,00 & 1 & 1,467 \\
\hline \multicolumn{5}{|c|}{ Brand Love } \\
\hline BL1 & 4,44 & 4,00 & 4 & 1,415 \\
\hline BL2 & 4,50 & 5,00 & 5 & 1,477 \\
\hline BL3 & 4,26 & 4,00 & 4 & 1,458 \\
\hline BL4 & 3,93 & 4,00 & 4 & 1,531 \\
\hline BL5 & 4,54 & 5,00 & 5 & 1,562 \\
\hline BL6 & 4,19 & 4,00 & 4 & 1,520 \\
\hline
\end{tabular}




\begin{tabular}{|c|c|c|c|c|}
\hline BL7 & 3,99 & 4,00 & 4 & 1,675 \\
\hline BL8 & 3,63 & 4,00 & 4 & 1,663 \\
\hline \multicolumn{5}{|c|}{ Emotional Attachment } \\
\hline EA1 & 2,04 & 1,00 & 1 & 1,389 \\
\hline EA2 & 2,26 & 2,00 & 1 & 1,507 \\
\hline EA3 & 2,42 & 2,00 & 1 & 1,567 \\
\hline \multicolumn{5}{|c|}{ Self-Expressive Brands Scale } \\
\hline \multicolumn{5}{|l|}{ Inner Self } \\
\hline SEB_IS_1 & 2,98 & 3,00 & 1 & 1,661 \\
\hline SEB_IS_2 & 3,15 & 3,00 & 1 & 1,683 \\
\hline SEB_IS_3 & 2,45 & 2,00 & 1 & 1,528 \\
\hline SEB_IS_4 & 2,45 & 2,00 & 1 & 1,507 \\
\hline \multicolumn{5}{|l|}{ Social Self } \\
\hline SEB_SS_1 & 4,04 & 4,00 & 5 & 1,666 \\
\hline SEB_SS_2 & 2,84 & 2,00 & 1 & 1,702 \\
\hline SEB_SS_3 & 2,91 & 3,00 & 1 & 1,675 \\
\hline SEB_SS_4 & 2,79 & 2,00 & 1 & 1,691 \\
\hline \multicolumn{5}{|c|}{ Self-Brand Connections } \\
\hline SBC1 & 2,56 & 2,00 & 1 & 1,579 \\
\hline SBC2 & 3,67 & 4,00 & 4 & 1,719 \\
\hline SBC3 & 3,19 & 3,00 & 4 & 1,649 \\
\hline \multicolumn{5}{|c|}{ Brand Loyalty } \\
\hline BLY1 & 3,63 & 4,00 & 4 & 1,640 \\
\hline BLY2 & 4,54 & 5,00 & 5 & 1,711 \\
\hline BLY3 & 2,45 & 2,00 & 1 & 1,609 \\
\hline BLY4 & 3,00 & 3,00 & 1 & 1,775 \\
\hline BLY5 & 1,92 & 1,00 & 1 & 1,397 \\
\hline BLY6 & 2,17 & 2,00 & 1 & 1,515 \\
\hline BLY7 & 2,66 & 2,00 & 1 & 1,822 \\
\hline BLY8 & 1,70 & 1,00 & 1 & 1,215 \\
\hline \multicolumn{5}{|c|}{ Word-of-Mouth } \\
\hline WOM1 & 3,62 & 4,00 & 5 & 1,825 \\
\hline WOM2 & 3,60 & 4,00 & 5 & 1,828 \\
\hline WOM3 & 3,07 & 3,00 & 1 & 1,731 \\
\hline WOM4 & 2,82 & 2,00 & 1 & 1,720 \\
\hline
\end{tabular}

Source: SPSS Ouput

The reason why, in some variables the values in mode are 1 is because, when talking about feelings the values can differ and many people can hate to love.

Bellow, we can see the descriptive statistics of latent variables in study 2 : 
Table 11. Descriptive Statistics of the Latent Variables - study 2

\begin{tabular}{|c|c|c|c|c|}
\hline & Mean & Median & Mode & $\begin{array}{l}\text { Standard } \\
\text { Deviation }\end{array}$ \\
\hline \multicolumn{5}{|c|}{ Fan Page Liking } \\
\hline FPL1 & 4,80 & 5,00 & 5 & 1,505 \\
\hline FPL2 & 3,86 & 4,00 & 4 & 1,575 \\
\hline FPL3 & 1,98 & 1,00 & 1 & 1,379 \\
\hline FPL4 & 5,52 & 6,00 & 7 & 1,560 \\
\hline FPL5 & 3,69 & 4,00 & 4 & 1,881 \\
\hline FPL6 & 2,65 & 2,00 & 1 & 1,673 \\
\hline \multicolumn{5}{|c|}{ Consumers' Engagement with Brand } \\
\hline \multicolumn{5}{|c|}{ Related Social Media Content } \\
\hline \multicolumn{5}{|c|}{ Consumption } \\
\hline CONS1 & 4,59 & 5,00 & 5 & 1,674 \\
\hline CONS2 & 2,93 & 2,00 & 1 & 1,869 \\
\hline CONS3 & 3,80 & 4,00 & 1 & 2,001 \\
\hline CONS4 & 2,52 & 2,00 & 1 & 1,676 \\
\hline \multicolumn{5}{|c|}{ Contribution } \\
\hline CONTR1 & 2,29 & 2,00 & 1 & 1,607 \\
\hline CONTR2 & 2,43 & 2,00 & 1 & 1,721 \\
\hline CONTR3 & 2,30 & 2,00 & 1 & 1,596 \\
\hline CONTR4 & 2,84 & 3,00 & 1 & 1,786 \\
\hline CONTR5 & 4,33 & 4,00 & 4 & 1,852 \\
\hline CONTR6 & 4,27 & 4,00 & 4 & 1,856 \\
\hline \multicolumn{5}{|c|}{ Social-Interactive Engagement } \\
\hline SIE1 & 2,12 & 1,00 & 1 & 1,441 \\
\hline SIE2 & 1,83 & 1,00 & 1 & 1,239 \\
\hline SIE3 & 2,73 & 2,00 & 1 & 1,633 \\
\hline SIE4 & 2,79 & 3,00 & 1 & 1,678 \\
\hline SIE5 & 3,74 & 4,00 & 4 & 1,790 \\
\hline SIE6 & 2,34 & 2,00 & 1 & 1,527 \\
\hline SIE7 & 2,65 & 2,00 & 1 & 1,712 \\
\hline SIE8 & 3,06 & 3,00 & 1 & 1,689 \\
\hline \multicolumn{5}{|c|}{ Brand Love } \\
\hline BL1 & 4,63 & 5,00 & 5 & 1,438 \\
\hline BL2 & 4,36 & 4,00 & $4^{\mathrm{a}}$ & 1,649 \\
\hline BL3 & 4,39 & 4,00 & 4 & 1,497 \\
\hline BL4 & 4,09 & 4,00 & 4 & 1,681 \\
\hline BL5 & 4,40 & 4,00 & 4 & 1,591 \\
\hline BL6 & 4,07 & 4,00 & 4 & 1,606 \\
\hline
\end{tabular}


BL7

BL8

Emotional Attachment

EA1

EA2

EA3

Self-Expressive Brands Scale

Inner Self

SEB_IS_1

SEB_IS_2

SEB_IS_3

SEB_IS_4

Social Self

SEB_SS_1

SEB_SS_2

SEB_SS_3

SEB_SS_4

Self-Brand Connections

SBC1

SBC2

SBC3

Brand Loyalty

BLY1

BLY2

BLY3

BLY4

BLY5

BLY6

BLY7

BLY8

Word-of-Mouth

WOM1

WOM2

WOM3

WOM4

$\begin{array}{llll}4,12 & 4,00 & 4 & 1,722 \\ 3,96 & 4,00 & 4 & 1,802\end{array}$

$\begin{array}{llll}2,33 & 2,00 & 1 & 1,584\end{array}$

$2,42 \quad 2,00 \quad 11,630$

$\begin{array}{llll}2,55 & 2,00 & 1 & 1,686\end{array}$

$2,67 \quad 2,00 \quad 11,745$

$2,70 \quad 2,00 \quad 1 \quad 1,760$

$\begin{array}{llll}2,23 & 2,00 & 1 & 1,534\end{array}$

$\begin{array}{llll}2,20 & 2,00 & 1 & 1,495\end{array}$

$\begin{array}{llll}2,47 & 2,00 & 1 & 1,617\end{array}$

$\begin{array}{llll}2,36 & 2,00 & 1 & 1,586\end{array}$

$\begin{array}{llll}2,27 & 2,00 & 1 & 1,533\end{array}$

$\begin{array}{llll}2,15 & 1,00 & 1 & 1,468\end{array}$

$\begin{array}{llll}2,26 & 2,00 & 1 & 1,574\end{array}$

$\begin{array}{llll}3,28 & 3,00 & 1 & 1,864\end{array}$

$\begin{array}{llll}2,66 & 2,00 & 1 & 1,719\end{array}$

$\begin{array}{llll}3,96 & 4,00 & 4 & 1,829\end{array}$

$\begin{array}{llll}4,36 & 4,00 & 4 & 1,790\end{array}$

$\begin{array}{llll}2,71 & 2,00 & 1 & 1,828\end{array}$

$\begin{array}{llll}2,94 & 3,00 & 1 & 1,833\end{array}$

$\begin{array}{llll}3,00 & 2,00 & 1 & 2,010\end{array}$

$\begin{array}{llll}2,65 & 2,00 & 1 & 1,803\end{array}$

$2,92 \quad 2,00 \quad 11,920$

$\begin{array}{llll}2,30 & 1,00 & 1 & 1,720\end{array}$

$\begin{array}{llll}4,36 & 5,00 & 5 & 1,881\end{array}$

$\begin{array}{llll}4,32 & 5,00 & 5 & 1,885\end{array}$

$\begin{array}{llll}3,79 & 4,00 & 4 & 1,956\end{array}$

\begin{tabular}{cccc}
3,61 & 4,00 & 1 & 1,976 \\
\hline & & Source: SPSS Ouput
\end{tabular} 


\section{Scales of Measurement}

As stated before, several scales were analysed concerning the relevance of the literature exposed earlier. All of the following, were adapted for several studies and authors relevant for the topic of investigation and were never seen together before.

The reason why, was because it was not found any study with all the variables we would like to study and, at the same time, we would like to propose a new model and verify if it fits the topic.

Below, at table 9 the list of variables and every item related with every construct. In front of every item, is already the code for every variable and will be used for now on whn corresponding to each item.

\section{Table 12. List of variables}

\section{Fan Page Liking}

FPL1- I find those products to be unique

FPL2- To get my queries solved

FPL3- Makes myself look cool

FPL4- To know more about it

FPL5- To have direct interaction with the company

FPL6- To interact with people like me on this fan page

adapted from Kudeshia et al. (2016)

\section{Consumers' engagement with brand-related social-media content - CEBRC}

Consumption

CONS1- I read posts related to Brand X on social media.

CONS2- I read fan page(s) related to Brand X on social networking sites.

CONS3- I watch pictures/graphics related to Brand X.

CONS4- I follow blogs related to Brand X. 
Contribution

CONTR1- I comment on videos related to Brand X.

CONTR2- I comment on posts related to Brand X.

CONTR3- I comment on pictures/graphics related to Brand X.

CONTR4- I share Brand X related posts.

CONTR5- I "Like" pictures/ graphics related to Brand X.

CONTR6- I "Like" posts related to Brand X.

adapted from (Schivinski et al., 2016)

Social-Interactive Engagement

SIE1 - I do quite a bit of socializing on this site

SIE2- I contribute to the conversation on this site

SIE3- I'm as interested in input from other users as I am in the regular content of this site

SIE4- A big reason I like this site is what I get from other users

SIE5- This site does a good job of getting its visitors to contribute or provide feedback

SIE6- I'd like to meet other people who regularly visit this site

SIE7- I've gotten interest in things I otherwise wouldn't have because of others on this site

SIE8- Overall, the visitors to this site are pretty knowledgeable about the topics it covers so you can learn from them.

adapted from Vernuccio et al (2015) and Pagani and Mirabello (2012)

\section{Brand Love Scale}

BL1- This is a wonderful brand

BL2- This brand makes me feel good

BL3- This brand is totally awesome

BL4- This brand makes me very happy

BL5- I love this brand

BL6- This brand is a pure delight.

BL7- I am passionate about this brand. 
BL8- I'm very attached to this brand.

adapted from Carroll and Ahuvia (2006)

\section{Emotional Attachment Scale}

EA1- This brand feels like an old friend to me

EA2- I feel emotionally connected with this brand

EA3- I feel a special bond with this brand

adapted from Thomson et al, 2005

Self-Expressive Brands Scale

Inner Self

SEB_IS_1- This brand symbolizes the kind of person I really am inside.

SEB_IS_2- This brand reflects my personality

SEB_IS_3- This brand is an extension of my inner self.

SEB_IS_4- This brand mirrors the real me.

Social Self

SEB_SS_1- This brand contributes to my image.

SEB_SS_2- This brand adds to a social 'role' I play.

SEB_SS_3- This brand has a positive impact on what others think of me.

SEB_SS_4- This brand improves the way society views me.

adapted from Carroll and Ahuvia (2006)

\section{Self-Brand Connections}

SBC1- This brand reflects who I am

SBC2- I can identify with this brand

SBC3- This brand suits me well.

adapted from Escalas and Bettman (2013)

\section{Brand Loyalty}

BLY1- I will buy this brand the next time I buy this kind of product 
BLY2- I intend to keep purchasing this brand

BLY3- I am committed to this brand

BLY4- 1 would be willing to pay a higher price for this brand over other brands

BLY5- This is the only brand of this type of product that I will buy

BLY6- When I go shopping, I don't even notice competing brands

BLY7- If my store is out of this brand, I'll postpone buying or go to another store

BLY8- I'll 'do without' rather than buy another brand

adapted from Chaudhuri and Holbrook (2001) and Carroll and Ahuvia (2006)

\section{Word-of-Mouth}

WOM1- I have recommended this brand to lots of people.

WOM2- I 'talk up' this brand to my friends.

WOM3- I try to spread the good-word about this brand.

WOM4- I give this brand tons of positive word-of-mouth advertising.

adapted from Carroll and Ahuvia (2006)

Source: Own elaboration

Considering all the exposed previously, the variables were carefully and strictly translated into the first language of the inquiries, which can be find at the end of this dissertation at the attachments area.

Considering there are plenty of latent variables in this study, the previous variables were measured using 7-point Likert scale, only.

The following table (Table 18) summarises the variables used and their original authors as long as the mention of important studies that have adapted them.

Also, will be explained how and why some variables were adapted. 
Table 13. List of variables and original scales

\begin{tabular}{lccc}
\hline \multicolumn{1}{c}{ Variables } & $\begin{array}{c}\text { Nr. of } \\
\text { itens }\end{array}$ & Original author(s) & $\begin{array}{c}\text { Author's that later } \\
\text { used the scales }\end{array}$ \\
\hline FPL Fan Page Liking & 6 & (N. Park et al., 2009) & $\begin{array}{c}\text { (C. M. K. Cheung } \text { et al., } \\
\text { 2011; Jahn and Kunz, } \\
\text { 2014; Kudeshia } \text { et al., } \\
2016)\end{array}$ \\
\hline
\end{tabular}

\section{CEBSM Consumers'}

Engagement with brand-

4+6 (Schivinski et al., 2016)

related social media content

\begin{tabular}{|c|c|c|c|}
\hline $\begin{array}{l}\text { SIE Social-Interactive } \\
\text { Engagement }\end{array}$ & 8 & (Calder et al., 2009) & $\begin{array}{c}\text { (Vernuccio et al., 2015) } \\
\text { (Pagani and Mirabello, } \\
\text { 2011) }\end{array}$ \\
\hline BL Brand Love & 8 & $\begin{array}{l}\text { (Carroll and Ahuvia, } \\
\text { 2006) }\end{array}$ & $\begin{array}{l}\text { (Albert and Merunka, } \\
\text { 2013; Wallace et al., } \\
\text { 2014) }\end{array}$ \\
\hline EA Emotional Attachment & 3 & (Thomson et al., 2005) & $\begin{array}{c}\text { (Batra et al., 2012; } \\
\text { Pedeliento } \text { et al., 2015) }\end{array}$ \\
\hline $\begin{array}{l}\text { SEB Self-expressive } \\
\text { Brands Scale }\end{array}$ & 8 & $\begin{array}{l}\text { (Carroll and Ahuvia, } \\
\text { 2006) }\end{array}$ & $\begin{array}{l}\text { (Wallace et al., 2014; } \\
\text { Huber } \text { et al., 2015) }\end{array}$ \\
\hline $\begin{array}{l}\text { SBC Self-Brand } \\
\text { Connections }\end{array}$ & 3 & $\begin{array}{l}\text { (Escalas and Bettman, } \\
\text { 2003) }\end{array}$ & - \\
\hline BLY Brand Loyalty & 8 & $\begin{array}{l}\text { (Chaudhuri and Holbrook, } \\
\text { 2001; Carroll and Ahuvia, } \\
\text { 2006) }\end{array}$ & $\begin{array}{c}\text { (Alnawas and Altarifi, } \\
\text { 2016) }\end{array}$ \\
\hline WOM Word-of-Mouth & 4 & $\begin{array}{l}\text { (Carroll and Ahuvia, } \\
\text { 2006) }\end{array}$ & $\begin{array}{l}\text { (Wallace et al., 2014; } \\
\text { Kudeshia } \text { et al., 2016) }\end{array}$ \\
\hline
\end{tabular}

Source: Own elaboration

Every scale is measured by a 7 point Likert scale where all the inquiries could choose from (1) "Entirely Disagree" to (7) "Entirely Agree", although the middle areas can incentive the inquiries to opt from this non-compromising scales.

Also, to properly analyse the scales of measure proposed before, it is necessary to validate their internal reliability.

The reliability of an instrument refers to its consistency and capacity of use in different contexts. Cronbach's alpha $(\alpha)$ is typically used to measure internal reliability, and 0,7 is 
suggested as the minimum acceptable score for indicating a satisfactory internal consistent reliability (Malhotra, 2007).

To ensure that we have internal consistency and indexes of reliability in our constructs we had to execute the Alpha of Crombach test. With this test we can understand if our constructs and scales are credible and if they might work in further analysis, namely Structural Equation Modelling, so the importance of finding its reliability. (Marôco, 2010)

In this particular model and context, Alpha of Crombach still the mostly used coefficient. The test reveals the mean of all the items that are included in the construct we are testing. It might goes from 0 to 1 , although all values below 0,6 prove that the items resulted in insufficient reliability (Malhotra, 2009). Concerning this topic, Hair et al., 2010 considers that the minimum we should achieve at Alpha of Crombach test, should be 0,7 .

Table 14. Indexes of Reliability of the latent scales of the conceptual model

\begin{tabular}{|c|c|c|}
\hline Variables & $\begin{array}{l}\text { Nr. of } \\
\text { items }\end{array}$ & $\alpha$ Crombach \\
\hline Fan Page Liking & 6 & ,655 \\
\hline $\begin{array}{l}\text { Consumers' Engagement with Brand- } \\
\text { Related Social Media Content }\end{array}$ & $4+6$ & ,882 \\
\hline Social-Interactive Engagement & 8 & ,894 \\
\hline Brand Love & 8 & ,962 \\
\hline Emotional Attachment & 3 & ,918 \\
\hline Self-Expressive Brands & 8 & ,944 \\
\hline Self-Brand Connections & 3 &, 890 \\
\hline Brand Loyalty & 8 & ,886 \\
\hline Word-of-Mouth & 4 & 942 \\
\hline
\end{tabular}

Source: Own elaboration using SPSS 
Concerning what has been stated earlier, the variables shown are all above 0,7 , except for the first one - Fan Page Liking - which is below. The other ones present a good index of reliability.

However, considering this was a first analyses of the index of reliability, all the items were revaluated in order to understand if the values could be better if some items were excluded.

The next table - table 14 - will show the items that were eliminated leading to new values of reliability.

Table 15. Indexes of Reliability of the latent scales of the conceptual model after eliminating some items

$\begin{array}{ccccc}\text { Variables } & \begin{array}{c}\text { Item } \\ \text { to }\end{array} & \text { Item description } & \begin{array}{c}\text { Nr. of } \\ \text { items }\end{array} & \begin{array}{c}\alpha \\ \text { Crombach }\end{array} \\ & \text { delete } & & \end{array}$

Fan Page Liking $\quad$ FPL4 To know more about it $\quad 5 \quad$,674

$\begin{array}{lllll}\begin{array}{l}\text { Social-Interactive } \\ \text { Engagement }\end{array} & \text { SIE5 } & \begin{array}{l}\text { getting its visitors to } \\ \text { contribute or provide } \\ \text { feedback. }\end{array} & 7 & , 899\end{array}$

Source: Own elaboration using SPSS

Since the variable Fan Page Liking couldn't be increased by the exclusion of any item, it was first though to exclude the total scale for this study. However, we will try to present the construct to second analysis - through Exploratory Factor Analysis - in order to understand if the variable should really be excluded. To help improving the Alpha of Crombach was excluded the 4 item (FLP4).

Considering the Social-Interactive Engagement the $5^{\text {th }}$ variable was also excluded.

For now on, the variables that were excluded earlier at table 14, will no longer be considered in the following analysis. 


\subsubsection{Sample Characterization}

\subsubsection{Data Collection}

Nowadays, Millennials are more and more interested in brands and about what they possess. More important than having, they value what they have, so they give great importance to the things they buy.

The aim of this study was to try to attract as many young adults possible and understand their relationship with brands. Since every Millennial is constantly online, this survey was distributed through that channel in order to reach as many respondents as possible.

The solution found was to use non-probabilistic sampling methods: convenience sample and snowball effect.

The previous consists on spreading the survey through friends, friends of friends, and for that, the social network Facebook was of great help. It was created a Facebook event to spread the survey. By identifying new people to answer the survey, it was created a snowball effect - someone would gather a different person to answer.

However, this methods were poor as the data gathered would not be representative of the universe of millennials, mainly based in Portugal. To overcome this problem, the both surveys were distributed via email to all students in University of Porto, Polytechnic of Porto, University of Aveiro, University of Minho and Lisbon University.

The studies were successfully sent to all students of University of Porto and only School of Nursering of Porto accepted to sent it also.

The first study was released from 25 of july 2016 until 2 of November 2016 and released again from 15 of july 2017 to 24 of july in order to improve the database.

The second survey was decided to be released since new improvements to this investigation were needed. It was released during $15^{\text {th }}$ of july 2017 and 30th of august.

\subsubsection{Sample Characterization}

This investigation aims to provide a relevant insight to the topic of analysis and that represents the most part - or at least a huge part - of millennials in Portugal. The reason why this study is stricted to the country it's because of its convenience. 
Although, as we were concerned that the results would be ambiguous, since we're talking about feelings, the objective was always to attract a great part of respondents. In order to achieve so, the two surveys were drawn to attract them - covering two different brand categories - and to have relevant data.

With this option we proved to have more effective and important data that would help to contribute to relevant study. In studies covering Structural Equation Modelling analysis, the dimension that is used as a model, is of 200 cases. (Kline, 2011; Hair et al., 2010). However, in the case of complex models, 200 respondents could not be sufficient to proceed with the analysis, considering some of the measurement model characteristics. So, the number that is mostly considered as valid is that the model for a model that has seven or less constructs (Hair et al., 2010), the minimum to consider would be of 150 . Since we have nine constructs and the valid response of 1135 inquiries (firstly were 1279, bur since we wanted to cover only millennials, we will consider only 1135 . Explanation will be considered later) we consider the size of the sample as very acceptable.

According to (Kline, 2011) the minimum acceptable to SEM analysis, is five time the number of variables.

The following table - table 15 - shows the relation of the inquiries of the survey and the brands they chose, in the first study:

Table 16. Respondents per Brand - Study 1

\begin{tabular}{llcccc} 
Valid & Frequency & Percentage & $\begin{array}{c}\text { Valid } \\
\text { Percentage }\end{array}$ & $\begin{array}{c}\text { Cumulative } \\
\text { Percentage }\end{array}$ \\
\cline { 3 - 5 } & Adidas Originals & 126 & 17,5 & 17,5 & 18,2 \\
Burberry & 25 & 3,5 & 3,5 & 21,7 \\
Chanel & 17 & 2,4 & 2,4 & 24,0 \\
Converse & 66 & 9,2 & 9,2 & 33,2 \\
H\&M & 102 & 14,2 & 14,2 & 47,4 \\
Levi's & 83 & 11,5 & 11,5 & 58,9 \\
Louis Vuitton & 11 & 1,5 & 1,5 & 60,4 \\
Michael Kors & 19 & 2,6 & 2,6 & 63,1 \\
Victoria's Secret & 31 & 4,3 & 4,3 & 67,4
\end{tabular}




$\begin{array}{lcccc}\text { Zara } & 235 & 32,6 & 32,6 & 100,0 \\ \text { Total } & 720 & 100,0 & 100,0 & \end{array}$

Source: SPSS Output

Bellow, we conduct the same exercise but covering the correspondents of the other study, covering technological and electronic brands.

Table 17. Respondents per Brand - Study 2

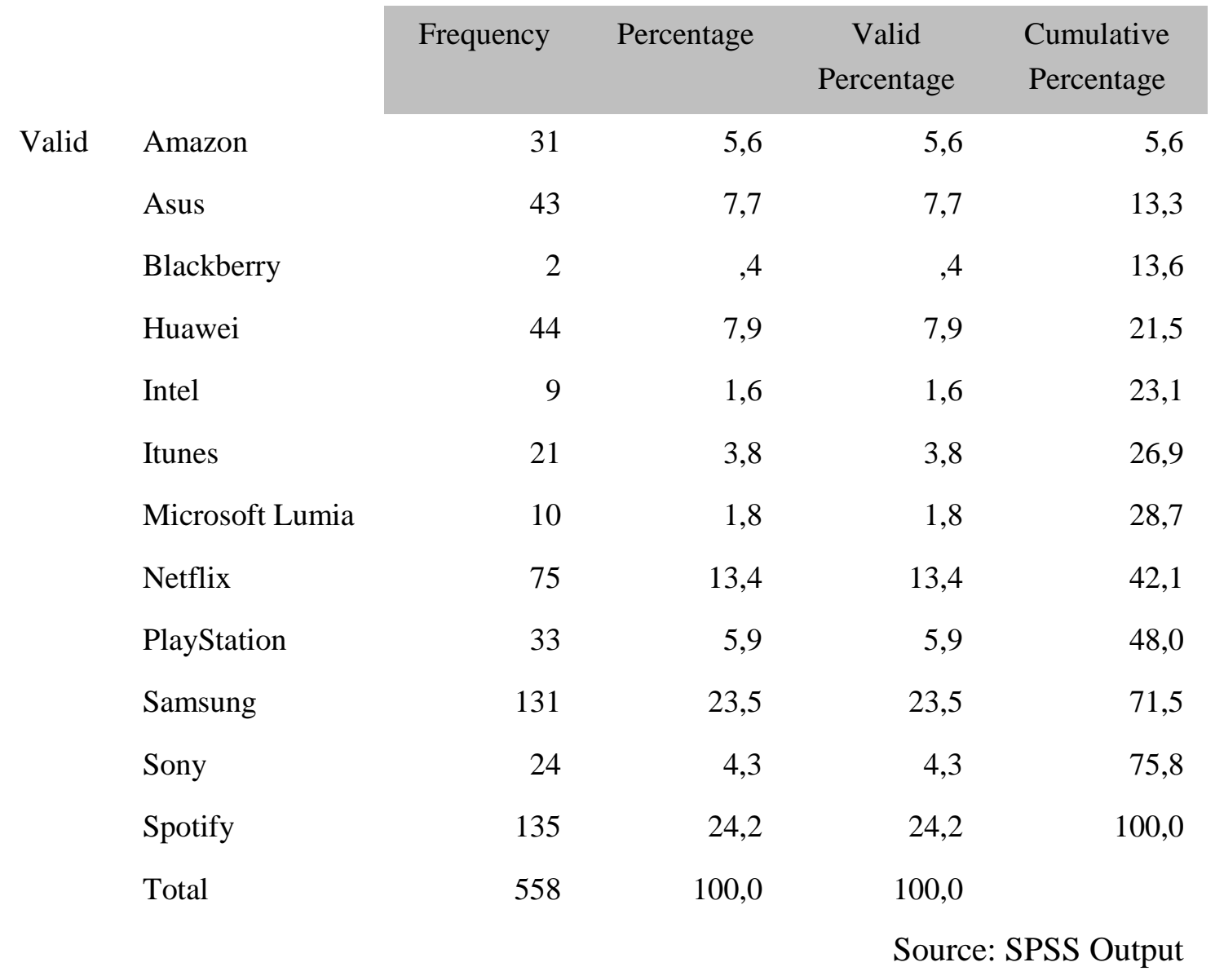

Considering that the survey had a pre-question to select the sample "Do you have any social network", the following table does not consider these respondents. Although, they have actually responded, they were immediately conducted to the end of the survey. Considering that, was decided that these respondents are not the sample of the study so it would be incorrect to contemplate them as characterization of the sample. 
The following table considers the 1278 valid responses. Although, since this study covers only millennials, were decided to be extracted all the respondents that were not included in the following ranges: $18-25$ and 26-35. Considering what was stated previously to this survey were considered valid 1135 responses, as the table 17 below, shows.

The characterization sample of each study separately can be found on Attachments area.

Table 18. Characterization of the sample

\section{Gender}

Female

Male

Age

Less than 18

$18-25$

26-35

$36-50$

More than 50

Education

Primary Education

Secondary Education

Licentiate Degree

Master or Doctor

Degree

Other

\section{Occupation}

Student

Student Worker

Employed

Unemployed

Retired

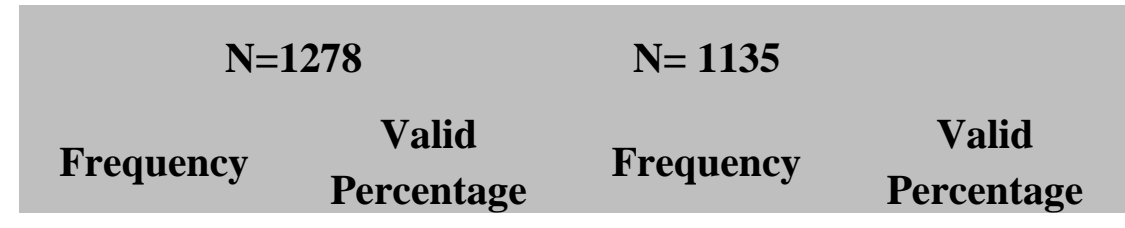

\begin{tabular}{ll|ll}
902 & 70.6 & 816 & 71.9 \\
375 & 29,3 & 318 & 28,0
\end{tabular}

5

0,4

0

0

912

80,4

223

71,4

223

19,6

113

17,4

8,8

0

0

1,7

0

0
3

247

624

397

7

775

254

220

27

2
0,2

19,3

48,8

31,1

0,6

60,6

19,9

17,2

2,1

0,2
0 0

230

576

326

3

20,3

50,7

28,7

0,3

757

66,7

199

17,5

159

14,0

20

1,8

0

Source: SPSS Output 
It comes as no surprise that most part of the respondents are students or student workers and that they have high degrees, with the most part selecting they have a Licentiate Degree. Considering that Millennials are the generation born between the earlier 80s till mid-90's the data matches the reality. Also, most part of the respondents were females.

\subsection{Structural Equation Modelling (SEM)}

The purpose of this study is to validate a conceptual model capable of analysing the constructs defined and their relations, namely Fan Page Liking, Consumers' Engagement

with brand-related social media content, Social-Interactive Engagement, Brand Love, Emotional Attachment, Self-expressive Brands Scale, Self-Brand Connections, Brand Loyalty, Word-of-Mouth

The Structural Equation Modeling (SEM) was considered to validate the hypothesis of the proposed model. The decision to consider SEM for this study remains in the fact that it allows a wide-ranging understanding of the conceptual framework. According to Hair et al. (2010, p. 634) SEM is "a family of statistical models that seek to explain the relationships among multiple variables (...) it examines the structure of interrelationships expressed in a series of equations, similar to a series of multiple regression equations".

Thus, since SEM was built upon factor analysis and multiple regression analysis, the cause-effect relationships between constructs (dependent and independent variables) and latent factors (observable variables) can be estimated.

The term constructs (also mentioned as latent variables) is defined as unobserved variables explained by observable variables. To understand the constructs, it's essential to understand the indicators (named also as observable or manifest variables). Opposed to the definition of constructs, indicators can be measured directly for themselves.

Henceforth, latent variables are measured by observable variables that can be collected by surveys, tests, among other methods of data collection (Hair et al., 2010; Marôco, 2010) Regarding this topic, Hair et al. (2010) added that one of the advantages of working with latent constructs passes by the fact that the measurement considers several items. This assumes relevance during investigations where the concept under study is complex, since the margin of error is decreased through an analysis that considers several perspectives and factors. On the other hand, latent variables can deliver results as accurate 
as possible since they adjust for errors by considering the misunderstanding/misinterpretation of the respondents.

According to the SEM terminology, we have two different types of constructs: exogenous constructs and endogenous constructs. While the former represents the independent variables that can explain the variables within the model (even if they are not include in the model), the latter represent the constructs within the model explained by the independent variables.

In conclusion, the Structural Equation Modelling is a behavioural explanatory model of dependent relationships capable of analysing the impact between variables.

\subsubsection{Factorial Analysis}

The Factorial Analysis is a methodological technique used to explain the difference between variables: latent and observable ones.

The Factorial Analysis is compose by two different parts. The first, Exploratory Factor Analysis (EFA) reduces the results, while the second one, Confirmatory Factor Analysis (CFA) confirms the results of the previous and checks the relationship between constructs.

\subsubsection{Exploratory Factor Analysis (EFA)}

EFA "explores the data and provides the researcher with information about how many factors are needed to best represent the data" as stated by Hair Jr. et al. (2010, p. 693). This analysis is typically used when there is no factorial information explaining correlations between the observed variables (Marôco, 2010). In this analysis, all measured variables are related to every factors, taking into account only the statistical results (not the theory behind the data).

The extraction method Principal Component Analysis (PCA) was used, in order to proceed with EFA. PCA finds structural patterns, after grouping similar items of a common variable, or which of the observed variables are influenced by specific latent variables.

Once EFA is unrestricted, latent factors could have impacted observed variables; this is why it is called exploratory. The relative importance of each factor is expressed by their factorial weight (Marôco, 2010). 
Bartletts's Test of Sphericity was used in order to discover if variables are uncorrelated in the population, and Kaiser-Meyer-Olkin (KMO) to define which components to use, in other words, the fitness of factor analysis (Malhotra, 2007; Marôco, 2010). Using KMO measure, components with values greater than 1 must be retained (Marôco, 2010). In the other hand, the same author also states that there are factors lower than 1 which can explain a great percentage $(9-10 \%)$ of the variance. This clarifies why the explained variance has to be around 60-70\%. According to Malhotra (2007, p. 612) "high values (between 0.5 and 1) indicate factor analysis is appropriate, and values below 0.5 imply that factor analysis may not be appropriate". Varimax (rotation method) was used to simplify and better interpret the factorial solution found (Marôco, 2010), and the principal components were analysed taking into account loadings as previously stated (greater than 0.5 for each component).

\subsubsection{Confirmatory Factor Analysis (CFA)}

After EFA is done, it is needed to interpret the obtained results. Confirmatory Factor Analysis was used to perform this evaluation. CFA is related to the confirmation of the factorial information that already exists, but must be confirmed under a different framework, in a more practical way, whether there is an impact of latent variables in manifest variables, depending on different contexts (Marôco, 2010). This way, "CFA is used to evaluate the quality of fit of a theoretical measurement model to the correlational structure observed between the manifest variables (items) (Marôco, 2010, p. 172)”.

This analysis validates how well the measured variables represents the construct by evaluating the validity and reliability of the scale (Hair et al., 2010). Cronbach's alpha $(\alpha)$ is usually used to measure internal reliability, but this method has been widely criticized by several authors (Hair et al., 2010; Marôco, 2010). Construct Reliability (CR) has been appointed as a better alternative to Cronbach's alpha and it represents "the measure of reliability and internal consistency of the measured variables representing a latent construct" (Hair et al., 2010, p. 689).

The degree to which the scale indeed measures what it is supposed to measure it is called validity (Marôco, 2010). There are several types of validity, but for this study we will only focus on convergent validity and discriminant validity. The first is established by positive and high correlations between the items of a given construct, is described by 
Malhotra (2007, p. 287) as "the extent to which the scale correlates positively with other measures of the same construct". This kind of validity is explained by Construct Reliability (CR) and Average Variance Extracted (AVE), which is described as a useful measure of consistency of the set of items representing a given construct (Hair et al., 2010; Marôco, 2010). In order to achieve convergent validity, AVE must be greater than 0.5 and CR must be higher than AVE (Hair et al., 2010). Furthermore, discriminant validity is "the extent to which a measure does not correlate with other constructs from which it is supposed to differ" (Malhotra, 2007, p. 287). In other words, it exposes how much a construct differs from the others, meaning that it isn't correlated with their constructs, measuring different factors of them (Hair et al., 2010; Marôco, 2010).

It is possible to proceed with the results of this analysis after giving important considerations regarding the survey elaboration, scales, variables, samples and theoretical considerations about Structural Equation Modeling (SEM).

After verifying this topics it is possible to continue with the structural model and the results given in all Structural Equation Modelling analysis. 


\section{Results}

In the following chapter will be presented the results of this study as well as the results of the hypothesis formulated.

\subsection{Conceptual Model}

As stated previously, the conceptual model will take into consideration the model presented before and will take into consideration the following variables: (1) Fan Page Liking; (2) Consumers' Engagement with Brand Related Social Media Content (Consumption and Contribution); (3) Social-Interactive Engagement; (4) Brand Love; (5) Emotional Attachment; (6) Self-Expressive Brands; (7) Self-Brand Connections; (8) Brand Loyalty; (9) Word-of-Mouth.

\subsubsection{Measurement Model}

The Measurement Model was calculated using Exploratory Factor Analysis (EFA). This test is particularly important in order to reduce data and also identify the most important items for each one of the constructs presented.

At this point were estimate the values of KMO and Bartlett Test for Sphericity and the Principal Component Analysis (PCA) of all the latent variables of the conceptual model. The results can be found on the following tables - table 24 and 25.

Table 19. Kaiser-Meyer-Olkin (KMO) and Bartlett Test of FPL, CEBSM, SIE, BL, EA, SEB, SBC, BLY, WOM

$\begin{array}{ccccccccc}\text { FPL } & \text { CEB } & \text { SIE } & \text { BL } & \text { EA } & \text { SEB } & \text { SBC } & \text { BLY } & \text { WO } \\ \text { SM } & & & & & & \text { M }\end{array}$

$\begin{aligned} & \text { KMO Measure of } \\ & \text { sampling adequacy }\end{aligned}$
$\begin{aligned} & \text { Sprox. } \\ & \text { Bartlett's }\end{aligned}$
$\begin{aligned} & \text { Apsto f } \\ & \text { Chi- }\end{aligned}$
$\begin{aligned} & \text { Sphericity } \\ & \text { Square }\end{aligned}$


To succefully do a factorial analysis, we need to prove we have correlations between variables. It is with Kaiser-Meyer-Olkin (KMO) Measure and Bartlett's Test of Sphericity that we can analyse this information. According to Malhotra (2009) the correlation can be validated if values are between 0,5 and 1 . By analysing the table presented before (table 19) we can perceive that all values are above 0,69 which is very positive. Brand Love actually has a very high value 0,932 which is pretty good since it is the main variable of analysis in this study. Also, Bartlett's Test of Sphericity shows that this analysis is statistically significant $(\mathrm{p}=, 000)$.

Since the construct Fan Page Liking is still below 0.7 - which indicates a mean sampling adequacy - was choose to be eliminated at this point, thus it might compromise the adequacy of the data.

Since the results of factor analysis were proved to be suitable for analysis, it is now necessary to proceed with the analysis through Principal Component Factor Analysis, in the table (

Once the suitability of factor analysis was proved to be a good way for analysing data, it is now necessary to proceed with the Principal Component Factor Analysis (table 19).

Table 20. Exploratory Factor Analysis - Principal Component Factor Analysis

\begin{tabular}{|c|c|c|c|c|c|c|c|c|}
\hline & 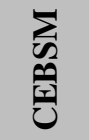 & 牙 & $\vec{\theta}$ & $\mathbb{x}$ & 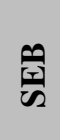 & 论 & $\overline{7}$ & $\begin{array}{l}\sum \\
0 \\
\vdots\end{array}$ \\
\hline CONS1 &, 569 & & & & & & & \\
\hline CONS2 &, 719 & & & & & & & \\
\hline CONS3 & ,642 & & & & & & & \\
\hline CONS4 & ,674 & & & & & & & \\
\hline CONTR1 & 825 & & & & & & & \\
\hline CONTR2 &, 847 & & & & & & & \\
\hline CONTR3 & ,846 & & & & & & & \\
\hline
\end{tabular}




\begin{tabular}{|c|c|c|c|c|c|c|c|}
\hline CONTR4 & ,700 & & & & & & \\
\hline CONTR5 & ,690 & & & & & & \\
\hline CONTR6 & 671 & & & & & & \\
\hline SIE1 & & ,754 & & & & & \\
\hline SIE2 & & ,773 & & & & & \\
\hline SIE3 & & ,767 & & & & & \\
\hline SIE4 & & 835 & & & & & \\
\hline SIE6 & & 819 & & & & & \\
\hline SIE7 & & 841 & & & & & \\
\hline SIE8 & & ,784 & & & & & \\
\hline BL1 & & & 872 & & & & \\
\hline BL2 & & & ,887 & & & & \\
\hline BL3 & & & ,918 & & & & \\
\hline BL4 & & & ,903 & & & & \\
\hline BL5 & & & ,913 & & & & \\
\hline BL6 & & & ,926 & & & & \\
\hline BL7 & & & ,891 & & & & \\
\hline BL8 & & & 842 & & & & \\
\hline EA1 & & & & ,900 & & & \\
\hline EA2 & & & & ,954 & & & \\
\hline EA3 & & & & ,933 & & & \\
\hline SEB_IS_1 & & & & & ,866 & & \\
\hline SEB_IS_2 & & & & & ,869 & & \\
\hline SEB_IS_3 & & & & & ,862 & & \\
\hline SEB_IS_4 & & & & & ,866 & & \\
\hline SEB_SS_1 & & & & & ,899 & & \\
\hline SEB_SS_2 & & & & & ,894 & & \\
\hline SEB_SS_3 & & & & & ,829 & & \\
\hline SEB_SS_4 & & & & & ,642 & & \\
\hline SBC1 & & & & & & ,877 & \\
\hline SBC2 & & & & & & ,907 & \\
\hline SBC3 & & & & & & ,935 & \\
\hline BLY1 & & & & & & & 859 \\
\hline BLY2 & & & & & & & ,918 \\
\hline BLY3 & & & & & & & ,534 \\
\hline BLY4 & & & & & & & ,647 \\
\hline BLY5 & & & & & & & ,782 \\
\hline BLY6 & & & & & & & ,825 \\
\hline BLY7 & & & & & & & ,652 \\
\hline BLY8 & & & & & & & 860 \\
\hline
\end{tabular}




\begin{tabular}{|l|l|l|l|l|l|l|l|c|}
\hline WOM1 & & & & & & & &, 910 \\
\hline WOM2 & & & & & & & &, 920 \\
\hline WOM3 & & & & & & & &, 934 \\
\hline WOM4 & & & & & & & &, 915 \\
\hline $\begin{array}{l}\text { Variance } \\
(\%)\end{array}$ & $\begin{array}{c}68,42 \\
\%\end{array}$ & $\begin{array}{c}63,497 \\
\%\end{array}$ & $\begin{array}{c}79,998 \\
\%\end{array}$ & $\begin{array}{c}86,330 \\
\%\end{array}$ & $\begin{array}{c}83,920 \\
\%\end{array}$ & $\begin{array}{c}82,193 \\
\%\end{array}$ & $\begin{array}{c}70,192 \\
\%\end{array}$ & $\begin{array}{c}84,629 \\
\%\end{array}$ \\
\hline
\end{tabular}

Source: Own elaboration with SPSS Output

Considering the data presented above and, according to (Malhotra, 2007) that states that the explained variance has to be around $60 \%-70 \%$, we can observe that all latent constructs meet this requirement.

Considering the other constructs, the percentages of explained variances are high coming as a good indicator. A special attention is needed to Emotional Attachment, Social Interactive Brands, Self-Brands Connections and Word-of-Mouth that present values above $80 \%$ which are a very good indicator.

Almost all the constructs during the PCA analysis, returned only one component for each construct. Exception made to Consumer brand related social media content, Social Interactive Brands - that comes of no surprises since they cover two components - inner and social self - and were divided equally, and Brand Loyalty, that returned two components. Since this scale is adapted from two different authors, the division is also acceptable.

Although, several analysis and tests were made considering this results, and was chosen to maintain them together - as presented earlier in the constructs - since the index of cumulative variance was higher if the components remained together. The table 25 presented before already contemplates this information.

Once the Principal Component Factor Analysis is finished, it is now necessary to confirm the results of our Exploratory Factor Analysis results. The way to confirm this values are through Confirmatory Factor Analysis (CFA), that was also explained earlier in this chapter. This method also allows an optimization of the measurement model, by improving its fit indexes.

The reliability of the scale was already proved before, and every necessary adjustments were made. Now it is necessary to evaluate the validity of the scale. 
The following table (table 20) show the results of the validity of each scale of the conceptual model.

Table 21. Construct Reliability (CR) and Average Variance Extracted (AVE) - own elaboration on SPSS

\begin{tabular}{|c|c|c|c|c|c|c|c|c|}
\hline & 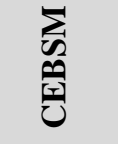 & 致 & 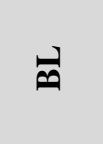 & 荎 & $\stackrel{\infty}{\mathbf{r}}$ & Uै & $\frac{1}{a}$ & $\begin{array}{l}\sum \\
0 \\
\vdots\end{array}$ \\
\hline AVE & 0,523 & 0,634 & 0,799 & 0,863 & 0,713 & 0,822 & 0,592 & 0,846 \\
\hline CR & 0,915 & 0,923 & 0,899 & 0,949 & 0,951 & 0,932 & 0,918 & 0,956 \\
\hline
\end{tabular}

Source: own elaboration with SPSS output

Considering the table presented earlier (Table 20), we can observe that the AVE of all constructs is superior to 0,5 and $\mathrm{CR}$ is equally or superior to 0,9 in all the constructs.

Through this analysis we can determine that the two indicators of validity are validated.. Also, we prove that convergent validity is also validated since the CR is greater than AVE is all constructs and AVE is superior to 0,5, proving that there exist positive and high correlations between the items of the constructs (Hair Jr. et al, 2010; Marôco, 2010).

Following, it is present the Measurement Model below, at table 27 and it involves all the nine latent variables. 
Figure 2 Measurement Model. Own elaboration

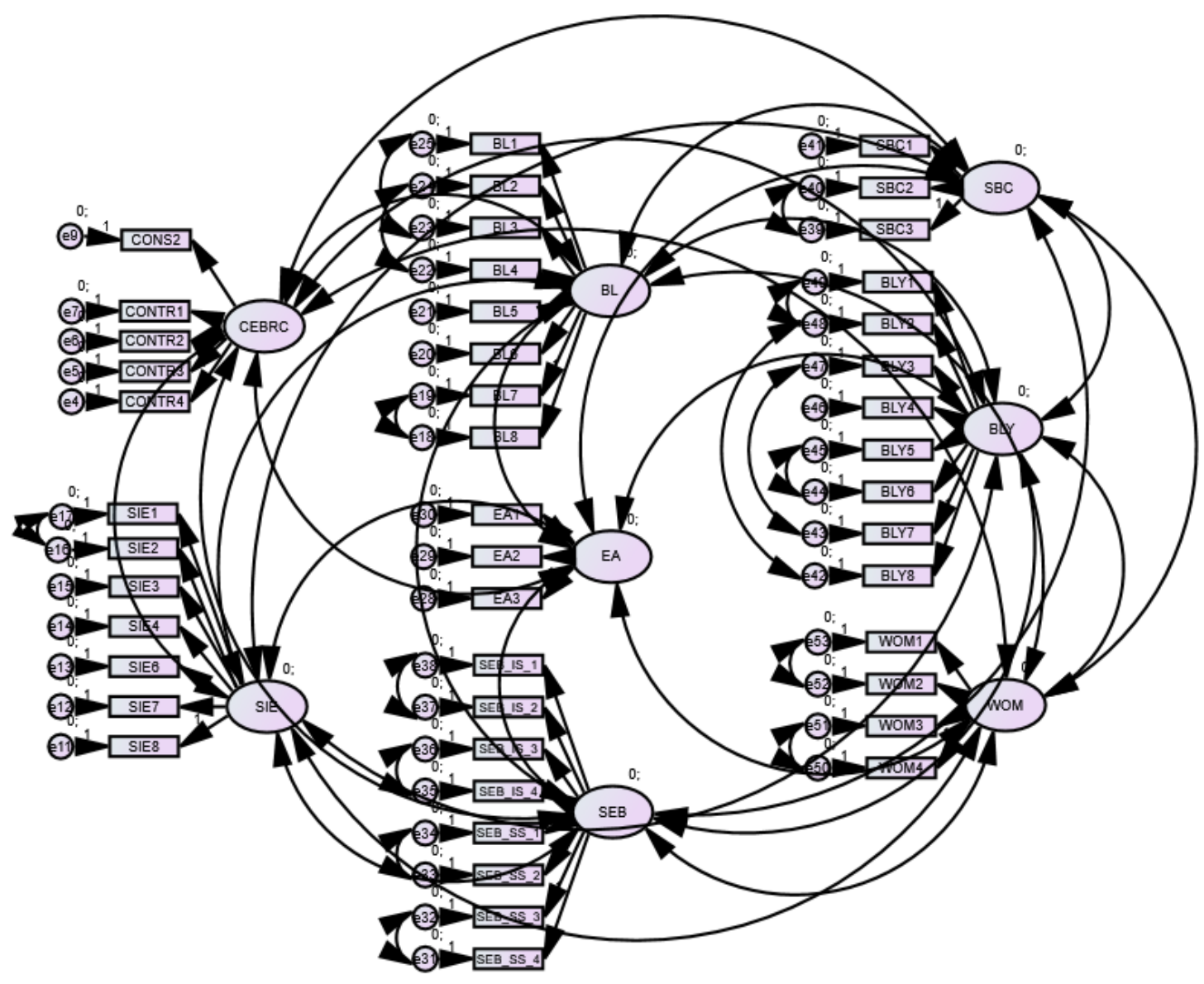

Source: AMOS

Some adjustments to the model were made, to improve model fit:

1. CONS1 (factor loading ,31), CONS3 (factor loading, 44), CONTR5 (factor ,32) and CONTR6 (factor loading ,30) were eliminated.

2. On the second try, CONS4 was factor loading, 51, so it was also eliminated since the model hadn't good fit already.

3. Fifteen covariances between errors were established (modification indices higher than 50). 
With these adjustments, the model fit improved consistently although the X2 / gl was not perfect. However, due to the size of the sample (above 1000 respondents) was chosen to proceed with the Structural Equation Model.

\subsubsection{Structural Model}

Once the measurement model was defined, it is now possible to continue with the analysis and determine the structural model.

It is important, at this point, to check the model fit of the model. Model fit "compares the theory to reality by assessing the similarity of the estimated covariance matrix (theory) to reality (the observed covariance matrix)" (Hair Jr. et al., 2010, p. 665).

In order to achieve the best fit values possible, were elaborate and tested several alternative models in order to achieve the best values.

At last, was chosen the model presented at figure 3 as the one who presented the best fit and the more relevance concerning the topic.

Table 19 presents the most common indexes used to measure the goodness of fit of the model, and the results of the fit indexes of both measurement model and structural model of this study.

Table 22. Statistics and indexes of goodness of fit of the models

\begin{tabular}{|c|c|c|c|}
\hline Statistics & Reference & $\begin{array}{c}\text { Index model fit - } \\
\text { Measurement } \\
\text { Model }\end{array}$ & $\begin{array}{c}\text { Index model fit } \\
\text { - Structural } \\
\text { Model }\end{array}$ \\
\hline $\mathrm{X}^{\wedge} 2 / \mathrm{gl}$ & $\begin{array}{l}>5-\text { Bad Adjustment } \\
{[2 ; 5]-\text { Tolerable Adjustment }} \\
{[1 ; 2]-\text { Good Adjustment }} \\
\sim 1-\text { Very Good Adjustment }\end{array}$ & 5,236 & 4,911 \\
\hline CFI & $<0.8-$ Bad Adjustment & ,923 & ,942 \\
\hline TLI & {$[0,8 ; 0,9]$ - Tolerable Adjustment } & ,916 & ,936 \\
\hline NFI & $\begin{array}{l}{[0,9 ; 0,95]-\text { Good Adjustment }} \\
\geq 0,95-\text { Very Good Adjustment }\end{array}$ & 907 & ,928 \\
\hline
\end{tabular}




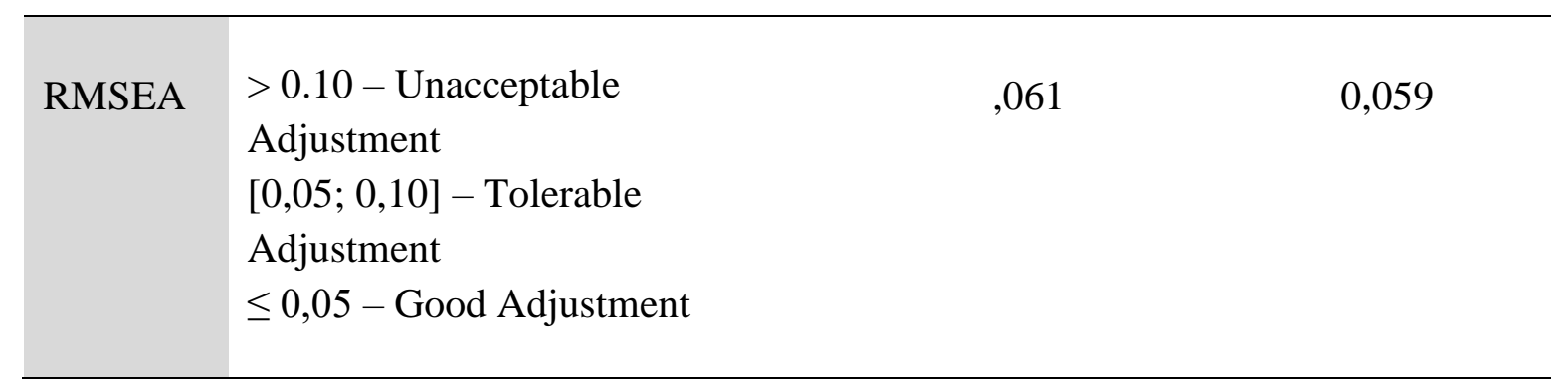

Source: Adapted from Marôco (2010); AMOS Output

The above model fit indexes (presented in table 21) contains 8 covariances between errors. Also was necessary to eliminate some items for the constructs and the variable concerning Social Brand Connections. The inclusion of this construct offered no relevance to the model, and the fit was not perfect. Also, it was the construct that offered less relevance to the model when comparing with others.

Taking a closer look to table 21 above, it is possible to observe that almost every index, with the exception of $X^{\wedge} 2 / g l$ and rmsea have good adjustment - the others demonstrate tolerable adjustment. However, all the values improved from the measurement model considerably. Also, was possible to achieve $\mathrm{X}^{\wedge} 2$ / gl below 5 , even with a sample above 1000 respondents, which was significantly positive.

Figure 3 below presents the standardized structural model (path diagram). 
Figure 3 Structural Model - Path Diagram

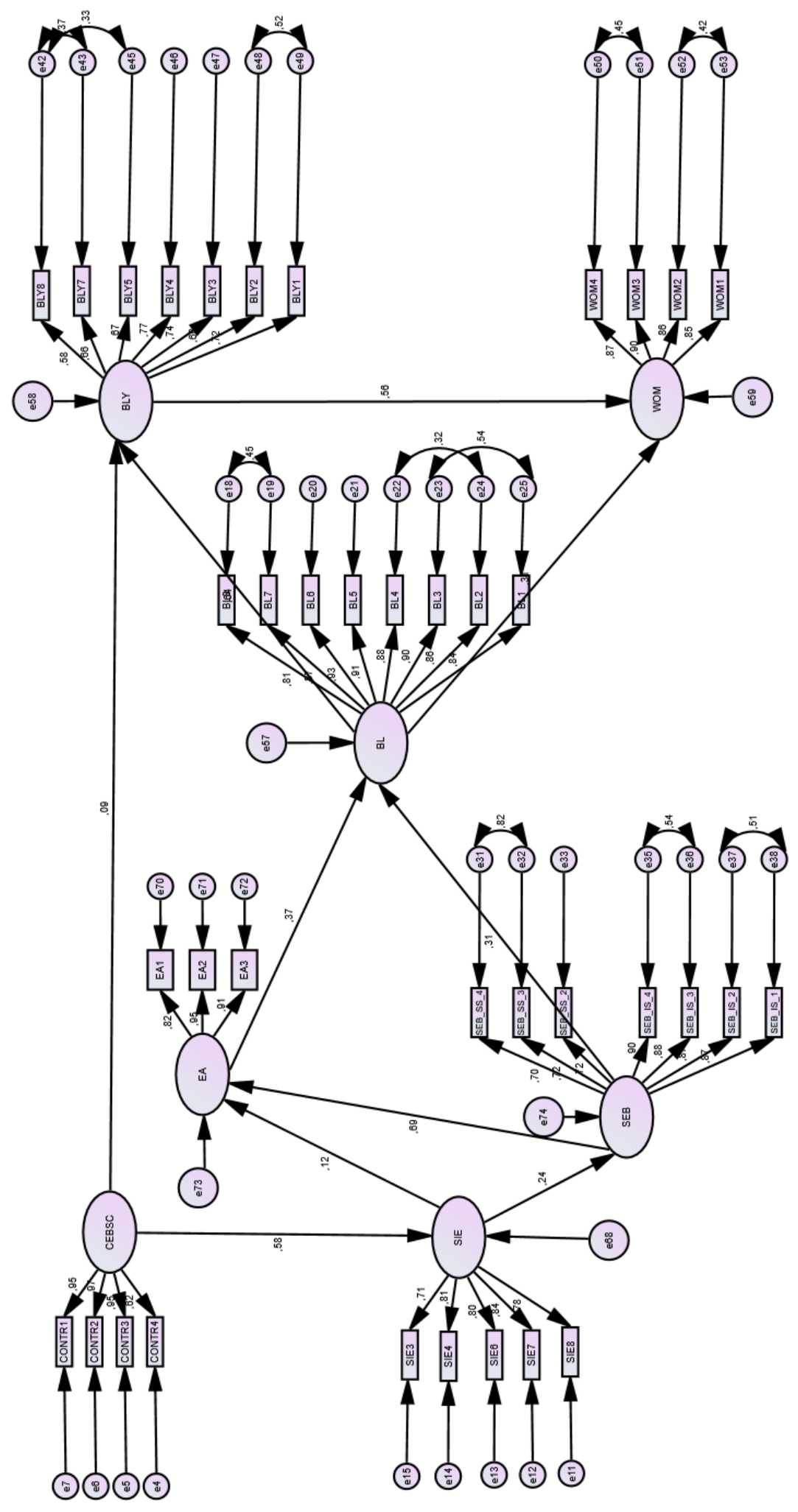

Source: Own Elaboration 
The standardized model shows a good loading on the relation between consumers' engagement with brand-related social-media content (CEBSC) and Social Interactive Engagement (SIE) $\rightarrow$ 0,58. Better loading also had the Self Expression Brands with Emotional Attachment $(0,69)$ and Brand Love and Brand Loyalty $(0,64)$ and Brand Loyalty and Word of Mouth $(0,56)$.

However there are low loading between some constructs, namely CEBSC and BLY $(0,9)$, for instance. This relation was expected since literature doesn't provide any information about this direct relation. However, as Schivinski suggested in this findings ((Schivinski et al., 2016) to try to apply in further research his scale to test purchase intentions and price premium. Although Brand Loyalty is not directly correlated with this point, since it's a consequence of the previous, we wanted to try the relation just to see if it worked. Also, the relation between SIE and BA is very low $(0,12)$ and SIE with SEB $(0,24)$. The relation between Emotional Attachment is 0,37 and SEB and BL is 0,31. Still, between the same values appears the relation between BL and WOM $(0,31)$.

Nevertheless, several attempts were made to increase these loadings. Many alternative models were tested with all the possible relations and with the exclusion of some low relations. However, the best indexes were the ones of the model presented earlier, which leads to the conclusion that this is the best one.

\subsubsection{Hypotheses Testing}

The validation of the hypotheses was made through SEM. It was made a factorial analysis that proved the convergent and discriminant validity of the constructs, which proved the constructs to proceed in the model, with the exception of Fan Page Liking, who was unproven reliability since alpha de Cronbach analysis.

Also, the SEM model proved that Self-Connection Brands (SBC) hadn't good fit with the model so we will opt to proceed the hypothesis testing without this relations.

In resume, below it is presented the conceptual model revisited: 


\section{Figure 4 Conceptual Model revisited}

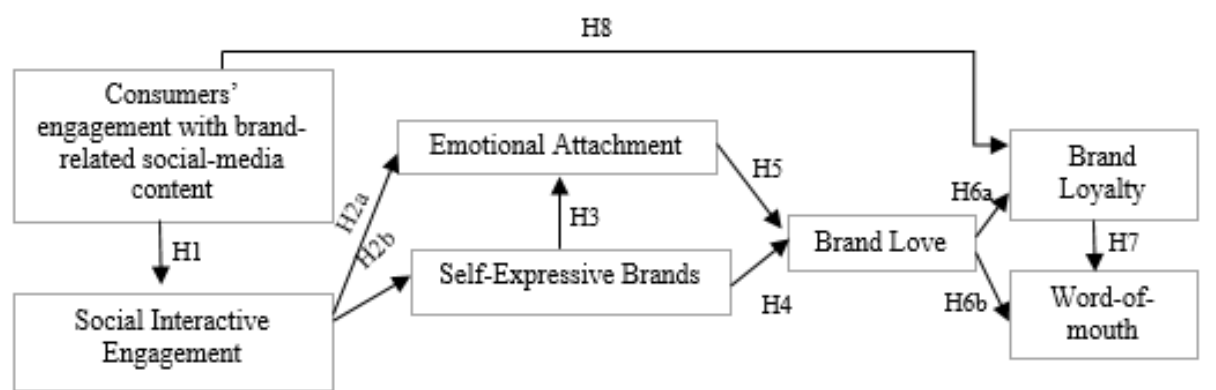

Source: Own elaboration

Next, we present the summary of hypotheses we are going to test after SEM outputs and analysis. The difference between the first hypotheses is that the ones concerning Fan Page Liking, and the ones considering relations with Self-Brand Connections were also eliminated. Also SEM proved a new relation (Self Expressive Brands and Emotional Attachment) which is going now to be considered.

\section{Table 23. Summary of hypotheses of investigation after SEM Analysis}

H1. Consumers' engagement with brand-related social-media content has a positive direct impact on Social Interactive Engagement.

H2a. Social Interactive Engagement has a positive direct impact on Emotional Attachment.

H2b. Social Interactive Engagement has a positive direct impact on Self-Expressive Brands.

H3. Self-Expressive Brands has a positive direct impact on Emotional Attachment.

H4. Self-Expressive Brands has a positive direct impact on Brand Love.

H5. Emotional Attachment has a positive direct impact on Brand Love.

H6a. Brand Love has positive impact on Brand Loyalty.

H6b. Brand Love has positive impact on WOM.

H7. Brand Loyalty has positive impact on WOM.

H8. Consumers' engagement with brand-related social-media content has a positive direct impact on Brand Loyalty.

Source: Own elaboration 
Below, and why we proved that the model had convergent and discriminant validity in the Confirmatory Factor Analysis, is it presented on table 23, the standardized total effects of the model:

Table 24. Standardized Total Effects (Direct + Indirect)

$\begin{array}{lrrrrrrr} & \text { CEBSC } & \text { SIE } & \text { SEB } & \text { EA } & \text { BL } & \text { BLY } & \text { WOM } \\ \text { SIE } & , 579 & , 000 & , 000 & , 000 & , 000 & , 000 & , 000 \\ \text { SEB } & , 137 & , 237 & , 000 & , 000 & , 000 & , 000 & , 000 \\ \text { EA } & , 163 & , 281 & , 688 & , 000 & , 000 & , 000 & , 000 \\ \text { BL } & , 102 & , 176 & , 559 & , 367 & , 000 & , 000 & , 000 \\ \text { BLY } & , 156 & , 112 & , 355 & , 233 & , 635 & , 000 & , 000 \\ \text { WOM } & , 119 & , 117 & , 371 & , 244 & , 664 & , 561 & , 000 \\ & & & & & \text { Source: AMOS Output }\end{array}$

Taking a closer look to the table presented above (table 23) it is possible to understand that Self-Expressive Brands, for example, is the construct with most impact on Emotional Attachment, meaning that SEB is the construct with more weight in the explanation of EA. Brand Love is undoubtedly the construct that has most impact on Brand Loyalty. Brand Loyalty and Brand Love have the most impact on Word-of-mouth, since they are directly correlated, however, Brand Love has most impact on the WOM construct than BLY. Social Interactive Engagement is, as known, only impacted by Consumer Engagement on Brand Related Social Media Content (CEBSC).

Below, table 24 displays the estimate loadings of the Structural Model and the p-value of the relations:

Table 25. SEM Model Estimates

$\begin{array}{ccccc} & & & \text { Estimate } & \text { P-value } \\ \text { SIE } & <--- & \text { CEBSC } & , 704 & * * * \\ \text { SEB } & <--- & \text { SIE } & , 391 & * * * \\ \text { EA } & <--- & \text { SIE } & , 209 & * * * \\ \text { EA } & <--- & \text { SEB } & , 740 & * * *\end{array}$




$\begin{array}{ccccc} & & & \text { Estimate } & \text { P-value } \\ \text { BL } & <--- & \text { SEB } & , 377 & * * * \\ \text { BL } & <--- & \text { EA } & , 419 & * * * \\ \text { BLY } & <--- & \text { BL } & , 391 & * * * \\ \text { BLY } & <--- & \text { CEBSC } & , 138 & * * * \\ \text { WOM }<--- & \text { BLY } & 1,066 & * * * \\ \text { WOM } & <--- & \text { BL } & , 359 & * * *\end{array}$

Source: AMOS output

Considering the values presented on the table 24 above, it is possible to validate all the hypotheses.

H1 suggested that CEBSC (Consumers' Engagement with brand-related social media content) had positive effect on Social Interactive Engagement. This hypotheses is validated $($ estimates $=, 704 ; p$-value $<0,001)$.

Also, the hypothesis concerning Social Interactive Engagement (SIE) - H2a and H2b -are also confirmed: Social Interactive Engagement has a positive effect on Self-Expressive Brands (estimates $=, 391 ; p$-value $<0,001)$ and Social Interactive Engagement has also a positive effect (besides lower) on Emotional Attachment (estimates = 209; $p$-value <0,001). Also hypothesis H3 to H5 were confirmed since the great values they present. H3.Self Expressive Brands have a positive effect on Emotional Attachment (estimates =,740; $p$-value $<0,001$ ); on H4. EA has a positive effect on Brand Love (estimates $=, 419 ;$-value $<0,001$ ) and SEB also have a positive effect on Brand Love (H5) (estimates $=, 377$; $p$-value $<0,001)$. The relations concerning Brand Love were also confirmed. On H6a BL was proved to have a positive effect on BLY (estimates = ,391; p-value $<0,001$ ) and on H6b BL has also a positive direct effect on WOM (estimates $=, 359 ; p$-value $<0,001)$.

H7 proposed that Band Loyalty had a positive effect on Word-of-Mouth. This hypotheses is also confirmed with the greatest values (estimates $=1,066 ; p$-value $<0,001$ ) although it was expected since literature diffusely confirms this relation.

H8 was a test with some findings presented on Schvinsky study. However, besides the low estimates values of the relation (which is not proved in literature) the hypotheses is confirmed due to its p-value which is also below 0,001 . 
Table 25 below sumarizes the results of the investigation hypothesis:

\section{Table 26. Results of Research Hypotheses}

\begin{tabular}{lll} 
& \multicolumn{1}{c}{ Hypotheses } & Result \\
H1 & $\begin{array}{l}\text { Consumers' engagement with brand-related social-media content has a positive } \\
\text { direct impact on Social Interactive Engagement. }\end{array}$ & Confirmed \\
H2a & $\begin{array}{l}\text { Social Interactive Engagement has a positive direct impact on Emotional } \\
\text { Attachment. }\end{array}$ & Confirmed \\
H2b & $\begin{array}{l}\text { Social Interactive Engagement has a positive direct impact on Self-Expressive } \\
\text { Brands. }\end{array}$ & Confirmed \\
H3 & Self Expressive Brands has a positive direct impact on Emotional Attachment. & Confirmed \\
H4 & Self-Expressive Brands has a positive direct impact on Brand Love. & Confirmed \\
H5 & Emotional Attachment has a positive direct impact on Brand Love. & Confirmed \\
H6a & Brand Love has positive impact on Brand Loyalty. & Confirmed \\
H6b & Brand Love has positive impact on WOM. & $\begin{array}{l}\text { Consumers' engagement with brand-related social-media content has a positive } \\
\text { Hirect impact on Brand Loyalty. }\end{array}$
\end{tabular}

Source: Own elaboration

Once results are presented, and before proceed with the discussion of the following and comparison with previous studies and literature review, we will now proceed with a multiple group analysis in order to see if applied in different contexts and samples the model would behave the same way.

\subsubsection{Multi Group Analysis}

In order to understand if the model responded equally when talking about different types of brands - remember that we conducted two studies: one concerning fashion and another one considering technology - we wanted to understand if the category influenced the perception of the model when analysing it separately. The principal objective is to understand "whether or not components of the measurement model and/or structural model are equivalent (i.e., invariant) across particular groups of interest" (Byrne, 2010: 197). 
For the analysis were created sub-samples considering the gathered data and was choose the variable "brand" - which represents which one of the groups named earlier - as mediator.

In order to achieve so, the multiple-group invariance analysis started with the estimation of the models to use. Byrne (2010) recommends to use four models, although for this particular study we will consider only to the analysis configural analysis and metric analysis.

The models chosen were:

M0 - Unconstrained model - without constraints (equal form).

M1 - Measurement weights - equal factor loadings.

Below, we can find the obtained results considering the models presented:

Table 22. Multiple-Group Invariance analysis

\begin{tabular}{c|ccccccccc} 
& CMIN & DF & $\chi^{2}$ /DF & CFI & RMSEA & PCLOSE & $\Delta$ DF & $\Delta \chi^{2}$ & $\Delta$ CFI \\
\hline M0 & 4247,697 & 1288 & 3,298 &, 932 &, 045 &, 000 & - & - & - \\
M1 & 4404,794 & 1319 & 3,339 &, 929 &, 045 &, 000 & 31 & 0,041 & 0,03 \\
& & & & & & & & & \\
& & & & & & & & &
\end{tabular}

Considering the previous table, we could consider different methods in order to test the results. We could first consider the existence of factor invariance if the results of $\Delta \mathrm{CFI}$ are until 0,01(G. W. Cheung and Rensvold, 2002). The way to calculate this values is by calculating the difference of any model with the Model 0 (unconstrained). We can also, consider the values to prove invariance if $\Delta \chi 2$ is until 0,01 , so we will consider the two options as an analysis metrics (Byrne, 2013).

First of all, we have to understand and analyse configure invariance of the data, who can be achieve by analysing the Model $0-$ which is without constraints. Since there are no previous models to test we will considerer the fit indexes of the model. (Dámasio, 2013; Byrne, 2013). 
Looking to the data, as proved in the sample all together in the analysis before, we can understand that the values of $\chi 2$ are tolerable - since they are between 2 and 5 - although we have to take into consideration the size of the sample, so the value presented can be seen as acceptable (Damásio, 2013). Also RMSAE values proved good adjustment since they are below 0,05. Also CFI proves good adjustment. So, considering the following, and accordingly to Damásio, 2013, the model suggests that there is invariance between the two groups and that both groups accept the same structure with the sae constructs. (Cheung and Rensvold, 2002).

The next analysis would be the metric invariance, presented with model 1 . However, with this values we can see that we have different perceptions. Firstly, we have $\Delta \chi 2$ that it is 0,041 which is proved to be up to 0,01 . We could immediately think that we would be in the presence of invariant analysis. However, Damásio (2013) states that differences in $\chi$ 2 are dependent on the size of the sample - as we explained earlier - so we will proceed with the $\triangle \mathrm{CFI}$ analysis that is proved to be below 0,01 . Accordingly to $\Delta \mathrm{CFI}$, when compared to the previous model, we can assume metric invariance.

Looking at the results, we can see that we have a problem: in one analysis we don't have proved invariance and in the other one we can assume metric invariance. To help explaining this, we will take into consideration Byrne (2010) ideas on the following. The author states that given its statistical stringency, it not expected that the $\chi 2$ difference test argues for evidence of noninvariance, while the CFI difference test argues for invariance. When this happens, the author states that the decision "of which one to accept is purely an arbitrary one and rests solely with each individual researcher". (Byrne, 2010).

Considering the analysis, and taking into consideration that we are in the presence of a significant sample, we will accept metric invariance, thus the sample is considered to perceive the constructs in the same way. 


\section{Discussion}

The base of the discussion of this study is the conceptual model created that takes into consideration some of the most relevant studies concerning this academic field.

Considering what was exposed previously, this section aims to discuss the results of the This section intends to discuss the results of this study and analysis. Will be analysed and discussed the results of the constructs of the model presented. Also, an analysis of the invariance of the construct between two different groups will follow.

First, it is important to look at the dimension of this study and the profile of the inquiries. The study conducted was composed of two different parts. The objective was to understand - after conducting the first study - if the respondents answered differently when talking about different types of brands and of different categories. Also, we wanted to understand if we could increase the sample of respondents by presenting different category brands.

The first study gathered 810 responses, while the second one gathered 588. Looking to this numbers we were satisfied with the sample conquered. Was now important to select the sample since didn't make sense to consider all.

The questionnaire was made to help selecting the sample. We had a first filter question (Do you have any social network?). Those who answered "No" would be conducted to the end of the survey, so this responses where not considered.

In the total, we have 1278 inquiries, a very good sample in order to test our model and hypothesis. Since, we wanted to study millennials and their relationship with brands, we decided to select the sample a little bit more. For this we filtered by age and were only considered respondents between two age ranges: 18-25 and 26-35, with a total of 1135 respondents.

So, regarding the millennials sample, this study concluded that $80,4 \%$ of the respondents were between 18 and 25 years old, $71,9 \%$ are females and the majority is a student $(66,7 \%)$ and have a Licentiate Degree $(50,7 \%)$. 
Regarding the presence on social networks, $98 \%$ of the respondents stated that they have a Facebook account. Concerning Instagram, 68\% have an account on this social network and $69 \%$ on Youtube. This findings state the idea of analysing the presence of brands on Facebook and Instagram as important for our sample universe.

When looking at which brands respondents preferred, besides the question indicates to chose the brand they most like, independently of the ability to buy - in brands concerning Fashion where chosen Zara and Adidas Originals and in the Technology sector were chosen Samsung and Spotify - it is important to highlight that Apple was not considered in this study due to its unpresence on social networks.

This results, offers new highlights about loved brands since most part of the studies cover luxury brands. In this case, this study shows, that regardless the ability to buy/have that brand, respondents opted to choose brands that are accessible. In previous studies, respondents also chose fashion and sports brands as their favourite on social networks. (Wallace et al., 2014) This tendency maintains also with the sample of this study. In the case of technology, the second most chosen was actually a free service.

Approximately $70 \%$ of respondents $(70,5 \%$ on fashion study and $72,3 \%$ on technology study) besides declaring they appreciate the chosen brand, don't follow the one on social networks. However, the ones who do, more than $80 \%$ would recommend the page to others.

After the above considerations, it is possible now to proceed with the discussion of the results of the constructs presented in the model.

This investigation aimed to answer some questions presented earlier that we remember at this point: (1) Is brand love effective in building true brand loyalty? (2) Does interactive engagement with brands and brand love contribute to build brand loyalty? (3) Does interactive engagement on social networks reflect millennials love of brands?

Given the results presented in chapter 7, we are now going to discuss the results to the questions presented above, considering the findings of this research. Given all the hypothesis we proposed to answer with the constructed model, it is now possible to confirm that all hypothesis of investigation were confirmed during the research, some with very good loadings. 
Below we are going to take a closer look to all of them in order to better understand our findings.

First, we proved that Consumer Brand Related Social Media Content had a positive impact on Social Interactive Engagement (H1). Many studies have been proving that consumers like to interact with brands and are more prone to positively engage in activities with the brand and, consequently develop feelings towards it (Brodie et al., 2011; Hudson et al., 2015).

Considering the relation between CEBSM and Brand Loyalty, besides the lower factor loadings, the relation proved confirmed (H8). This relation is new on literature and was suggested since Schivinsky et al., suggested to engage the CEBSM variables into Purchase Intentions and Willingness to Pay a Premium Price variables. Concerning the suggestions we tried to apply the construct to a proved consequence (Chaudhuri and Holbrock, 2001) of the following Brand Loyalty. This confirmed hypothesis is particularly interesting since literature doesn't prove this relationship. The adaption and inclusion of this dimension in further research could be of great relevance to understand how to attract faithful consumers through social networks.

The two hypothesis concerning Social Interactive Engagement ( $\mathrm{H} 2 \mathrm{a}$ and $\mathrm{H} 2 \mathrm{~b})$ were also a test in this study that had been proved correct. In the study of Vernuccio et al., 2015, the author tried to indirectly prove a connection between SIE and BL, through Social Identity. Since in the findings the link between SIE and BL proved non-significant, we chose to maintain this finding and not directly connect this variables. However, since we didn't use Social Identity variable to link the previous we have to link the variables. The use of Emotional Attachment proved correct, helping in the valorisation of the study and the model presented and to literature. Although, literature doesn't prove this relations, Vernuccio et al., 2015 findings suggest that people identify with social groups (in this case social networks pages) in terms of attachment to the brand (ibidem).

The next hypothesis, concerning the relation between SIE and Self-Expressive Brands was also tested and proved correct. There are no relation of this variables relation in literature, which is quite interesting to prove, although Wallace et al., 2014 tried to establish relations with Self-Expressive Brands on Social Media. With this idea ahead we 
chose to evaluate if we could prove Vernuccio et al., 2015 findings on the influence of SIE on BL through psychological effects also with Self-expressive Brands.

In the same logic, H5 tried to establish a relationship between SEB and Brand Love. The relation proved also correct in line with findings of other studies in literature (Wallace et al., 2014, Carroll and Ahuvia, 2006).

Literature enhances that brands that allow fans to express themselves on social networks, for instance, are more likely to become loved brands (Wallace et al., 2014). Also, the same study proved that when consumers engage with self-expressive brands online, brand love mediates the relationship between those brands and WOM. This findings were also supported by Batra et al., 2012 who stated that loved brands contribute to consumers express their true self.

Nevertheless, there are not proved relationship with Self-Expressive Brands and Brand Attachment (H4) we chose to try this relationship since as exposed before EA is an emotional construct that tries to explain why consumers might get emotional over a brand and why they try to maintain a relationship with it (Chaudhuri and Holbrook, 2001; C. W. Park et al., 2010; Albert and Merunka, 2013). Besides, being considered to establish les stronger bonds with brands than BL we tried to expose the construct to a possible relation with Emotional Attachment in order to understand if the following might also prove right. The result was a relation with one of the most high estimates relation values of the construct which proved this connection to be considerable relevant and a contribution to further research.

In almost every literature concerning the topic of Brand Love and Emotional Attachment, EA is presented as a potential antecedent. We had to covered this relation - firstly because it wouldn't be correct not to use it and then because it improved the overall model fit (Thomson et al., 2005; Carroll and Ahuvia, 2006).

This study also proves that Brand Love has a positive direct effect on Brand Loyalty $(\mathrm{H} 2 \mathrm{a})$. Literature has proven this relationship on several other studies (Albert and Merunka, 2013; Batra et al., 2012; Hwang and Kandampully, 2012; Patwardhan and Balasubramanian, 2011; Carroll and Ahuvia, 2006). Since Brand Loyalty it is largely acceptable on literature as a powerful outcome of Brand Love, it had to be included on this investigation also, which was proven correct. This findings suggest that brand love 
"is a meaningful mode of consumer satisfaction that is linked to desirable postconsumption behaviour" (Carroll and Ahuvia, 2006: 86).

Also, when consumers engage with brands it is proved that loved brands are more likely to have direct impact on WOM (H6b). This study supports the findings of Kudeshia et al.(2016), Wallace et al., (2014), Albert and Merunka (2013), Carroll and Ahuvia, (2006). Also Batra et al., 2012 had confirmed the influence of Brand Love with WOM. Also, our findings considering Standardized Total Effects (Direct + Indirect) of the model proved that BL was the construct with the most relevant effect on WOM. Since literature widely connects this two constructs were of no great surprise that this hypothesis was confirmed. However, the findings demonstrate a good fit of the model and consequently demonstrates the appropriateness of the constructed model and his applicability in this research.

Finally, WOM is also proved as an outcome of Brand Loyalty with the greatest loading values of all the hypothesis tested. The findings are in line with other research concerning the topic. It has been diffusely tested on literature than when a consumer becomes loyal to a brand it more prone to become a brand ambassador of the brand. Studies correlate that WOM is more effective on attracting new consumers - if it comes for someone they acknowledge or admire - than by advertising itself. Also, the studies proves as indirect positive relation between Brand Love and WOM which increases the importance of this construct when we are talking about loved brands. The findings are in line with the existent literature and are proved as applicable in the context of this research as well.

With all the hypothesis confirmed and the questions positively answered we wanted to test if the model behaved equally for the two studies conducted. The model behave well in the previous research so we wanted to test it with a smaller sample and different brand categories the results would maintain.

To answer that, a multi-group factor analysis was realized. The results showed that we have configural and metric analysis (the ones we chose to study in this research) in both different studies, covering Fashion and Technological brands.

This findings suggest that both samples considered the items and the variables the same, proving our model to be strong and possible to be implemented in other research. 
After discussing the results, the conclusions and limitations of this study will consequently be presented. Also, some considerations for future research will be given. 


\section{Conclusion}

It was love at the first sight! This romantic deeply-analysed and stated over the years' reference has inspired many lovers and developed the idea of true-amazing type of love. However, not everyone can fall at first sight, as Romeo and Juliet's, for instance. Some relationships take time and mature to grow up. With others, the intensity of love drops significantly over time (Huber et al., 2015).

The same happens with brands. Some brand relationships go through a long and solid way, while others stable in a blink of an eye (Langner et al., 2014). Some authors believe that feelings of love and passion for a brand primarily arises when, somehow, that brand aims to speak directly to the consumers' inner-self, as part of its personality (Hwang and Kandampully, 2012; Huber et al., 2015). Several authors actually believe that hedonic aspects of a consumer-brand relationship are strongly related to emotional responses to brands, namely brand love. (Carroll and Ahuvia, 2006; Hwang and Kandampully, 2012; Huber et al., 2015).

Although emotions are never-ending theme on marketing research marketing in the last years, we are only beginning to understand the important role of emotions in marketing communications (Bagozzi et al., 1999 apud Hudson et al., 2015).

Researchers are trying also to comprehend the impact of brand emotion on the new technological are and among young consumers. This study also wants to test that hypothesis, since traditional marketing is not enough anymore to attract consumers.

Companies have commonly embraced social media because of its potential for engagement and collaboration with consumers. Through social media, marketers can gain rich, unmediated consumer insights, faster than ever before, and can seek loyalty through them (Hudson et al., 2015). Also, it is believed that consumers that engage with their favourite brands through social media have stronger relationships with those brands compared with consumers who do not interact with their favourite brands using social media. (Hudson et al., 2015). It is also accepted that positive experiences from direct brand interaction via social media will lead to repeat purchases (ibidem) and, possibly word-of-mouth. 
Aware of this topics, is the aim of this dissertation to explore brand love connections, namely on social networks, and understand if it can lead to Brand Loyalty and positive Word-of-Mouth.

First, in the literature revision, we try to highlight some of the main topics of this dissertation, covering consumer-brand relationships, to brand emotion constructs - from brand love, going through emotional attachment and brand passion - to brand loyalty and finishing in engagement. On this exposition of different topics and constucts, we tried to connect all of them and give different and valuable perspectives from the most influent authors.

Next, and in order to answer this objectives, we develop the methodology of this study. Was decided to implement a quantitative methodology in order to obtain a model of brand love covering constructs that have never been seen together before. This was constructed using the Structural Equation Modelling (SEM).

To fulfil this ambitions, were conducted two investigations in the form of surveys - which covered two different categories of brands. These were distribute to students in different faculties and on Facebook, leading to 1135 valid responses. The method, has stated earlier, was new and elaborated for this dissertation. The variables and items were adapted from several studies in literature: Consumers' Engagement with brand-related social media content - Schivinsky et al, 2016; Social-Interactive Engagement - Vernuccio et al., 2015; Brand Love - Carroll and Ahuvia, 2006; Emotional Attachment - Batra et al., 2012; Selfexpressive Brands Scale - Wallace et al., 2014; Chaudhuri and Holbrook, 2001 and Carroll and Ahuvia, 2006; Word-of Mouth - Wallace et al., 2014. It is important to highlight that, at this time, we chose to present the variables that actually belong in the model conceived and the authors from whom the variables where directly adapted. In some, the original scales are presented along the dissertation.

In the first study were also contemplated two more variables: Fan Page Liking and Self Brand Connections. However, during factor analysis the constructs appeared as as bad fit for the model, so we chose to extract them since the model offered better results without these constructs.

The results of the analysis proved the reliability and validity of our model. With the model we proposed, all of our hypothesis were confirmed and validated. 
First, we proved that Consumer Brand Related Social Media Content had a positive impact on Social Interactive Engagement (H1). Many studies have been proving that consumers like to interact with brands and are more prone to positively engage in activities with the brand and, consequently develop feelings towards it. Although this hypothesis were almost sure to fulfil our expectations, we also tried to connect CEBSM with Brand Loyalty (H8), since Schivinsky et al., (2016) suggested at his findings to try to correlate his constructs with purchase intentions. Although we didn't covered Purchas Intentions Constructs in this investigation, we tried to connect it with Brand Loyalty, which was proved correct. The findings suggest that consumers who contribute to the page might become loyal customers.

Vernuccio et al., 2015, tried to indirectly prove a connection between SIE and BL (H2a), through Social Identity. Since we didn't covered this construct (and in his findings they were proved as non-significant) we suggested to link it EA which was proved correct. Although, literature doesn't prove this relations, Vernuccio et al., 2015 findings suggest that people identify with social groups in terms of attachment to the brand (ibidem). The next hypothesis also covering SIE (H2b) tried a relation with Self-Expressive Brands was also tested and proved correct. Besides there was no relation in literature concerning this topics, Wallace et al., (2014) tried to establish relations with Self-Expressive Brands on Social Media. With this idea ahead we chose to evaluate if we could prove Vernuccio et al., (2015) findings on the influence of SIE on BL through psychological effects also with Self-expressive Brands and it was accomplished.

In the same logic, in H5 we tried to establish a relationship between SEB and Brand Love. The relation proved also correct in line with findings of other studies in literature (Wallace et al., 2014, Carroll and Ahuvia, 2006). Wallace et al., (2014) has found that fans to express themselves on social networks are more likely to become in love with the brand. Also, the same study proved that when consumers engage with self-expressive brands online, brand love mediates the relationship between those brands and WOM. This findings were also supported by Batra et al., 2012 who stated that loved brands contribute to consumers express their true self.

Also, in $\mathrm{H} 4$ concerning the relation between Self-Expressive Brands and Brand Attachment literature doesn't cover this relationship also. We chose to try this 
relationship since EA is an emotional construct that tries to explain why consumers might get emotional over a brand and why they try to maintain a relationship with it (Chaudhuri and Holbrook, 2001; C. W. Park et al., 2010; Albert and Merunka, 2013). The result was a relation with one of the most high estimates relation values of the construct which proved this connection to be considerable relevant and a contribution to further research. In almost every literature concerning the topic of BL, EA is presented as a potential antecedent. We had to covered this relation - firstly because it wouldn't be correct not to use it and then because it improved the overall model fit.

Also, the hypothesis covering the relations between BL and BLY (H6a); Brand Love and WOM (H6b) and BLY with WOM (H7) had to be incorporated. Literature has proven this relationships (Albert and Merunka, 2013; Batra et al., 2012; Hwang and Kandampully, 2012; Patwardhan and Balasubramanian, 2011; Carroll and Ahuvia, 2006, fo example) and we also connected them concerning our topic of analysis and our purpose. This relations, besides many times studied in literature, have never appeared in the way we present, before. This findings suggest that, besides improving and presenting a new model to analyse Brand Love and Brand Loyalty, our method and research was proved correct and the indexes of this relations were proved with meaningful values.

Besides, proving our model and constructs' relations, we were not satisfied and wanted to test if our sample would perceive our study as equal even when considering different groups. We chose to conduct a Multi Group Factor Analysis in order to understand if, we devided our sample in the two studies conducted - concerning Fashion and Technological Brands we would obtained the same perception to the model.

This findings suggest that both samples considered the items and the variables the same, proving our model to be strong and possible to be implemented in other research.

To summarize, we can consider the results obtained with this investigation very positive since we aimed to prove and validate our theoretical investigation model. We aim that this study offers highlights concerning the topic of brand love in social media and interactive engagement and helps brands understand the potential of this relations in managerial areas. 
Although the topic is being investigated nowadays, it is the first time we try to connect brand love and brand loyalty with self-expressive brands, social interactive engagement and consumers' brand social media content all together. This proves that when consumers contribute in brand pages and engage with this social interactive engagements they might perceived this brands as part of their self and as an extension of their personality. That might develop feelings of attachment towards the brand, brand love and consequently brand loyalty and positive word-of-mouth. Regardless, this findings, we also incorporated one of the suggestions in Schivinsky et al. (2016) findings that were also proved correct. These findings can be improved or applied to further research in other areas or incorporating some new constructs. One idea is trying to apply it to services categories, since investigation proved that Spotify - which is a service - was the second chosen brand in the study concerning Technology.

However, this study covers some limitations that are important to highlight. First, the sample, although was proved and very relevant and one of the most powerful topics of this investigation (1135 valid responses) were gained through convenience. The major part of the sample are students (although the investigation covers millennials) but mainly focus on students of Porto. This sample could also cover some young millennials already in the market and/or contemplate youngers from another countries.

The other limitation is the novelty of the model. Some relations were not proved in literature besides being considered proved and correct. Further research should investigate more this topic of analysis and better analyse this constructs in order to understand if they have applicability in several other investigations. 


\section{References}

Ahuvia, A. C. (2005). "Beyond the Extended Self: Loved Objects and Consumersl' Identity Narratives". Vol. 32.

Albert, N., and Merunka, D. (2013). "The role of brand love in consumer-brand relationships". Vol. 30(3), 258-266.

Albert, N., Merunka, D., and Valette-Florence, P. (2008). "When consumers love their brands: Exploring the concept and its dimensions". Vol. 61.

Albert, N., Merunka, D., and Valette-Florence, P. (2009). "The Feeling of Love Toward a Brand: Concept and Measurement". Vol. 36.

Albert, N., Merunka, D., and Valette-Florence, P. (2013). "Brand passion: Antecedents and consequences". Vol. 66.

Alnawas, I., and Altarifi, S. (2016). "Exploring the role of brand identification and brand love in generating higher levels of brand loyalty". Vol. 22.

Batra, R., Ahuvia, A., and Bagozzi, R. P. (2012). "Brand Love". Vol. 76, 1-16.

Bowlby, J. (1979). The Making and Breaking of Affectional Bonds. Tavistock, London.

Brodie, R. J., Hollebeek, L. D., Jurić, B., and Ilić, A. (2011). "Customer engagement: Conceptual domain, fundamental propositions, and implications for research". Vol. 14(3), 252-252 - 271.

Buttle, F. (2010). Customer Relationship Management: concepts and technologies (2th edition ed.): Butterworth:Heinemann.

Byrne, B. M. (2013). Structural Equation Modeling With AMOS: Basic Concepts, Applications, and Programming, Second Edition: Taylor \& Francis.

Calder, B. J., Malthouse, E. C., and Schaedel, U. (2009). "An Experimental Study of the Relationship between Online Engagement and Advertising Effectiveness". Vol. 23(4), 321.

Calefato, F., Lanubile, F., and Novielli, N. (2015). "The role of social media in affective trust building in customer--supplier relationships". Vol. 15.

Carroll, B. A., and Ahuvia, A. C. (2006). "Some antecedents and outcomes of brand love". Vol. 17, 79-89.

Chaudhuri, A., and Holbrook, M. B. (2001). "The Chain of Effects from Brand Trust and Brand Affect to Brand Performance: The Role of Brand Loyalty". Vol. 65, 81-93. 
Cheung, C. M. K., Chiu, P.-Y., and Lee, M. K. O. (2011). "Online social networks: Why do students use facebook?". Vol. 27(4), 1337.

Cheung, G. W., and Rensvold, R. B. (2002). "Evaluating Goodness-of-Fit Indexes for Testing Measurement Invariance". Structural Equation Modeling: A Multidisciplinary Journal, Vol. 9(2), 233-255.

Damásio, B. F. (2013). "Contribuições da Análise Fatorial Confirmatória Multigrupo (AFCMG) na avaliação de invariância de instrumentos psicométricos". PsicoUSF, Vol. 18, 211-220.

Dijkmans, C., Kerkhof, P., and Beukeboom, C. J. (2015). "A stage to engage: Social media use and corporate reputation". Vol. 47, 58.

Escalas, J. E., and Bettman, J. R. (2003). "You Are What They Eat: The Influence of Reference Groups on Consumers' Connections to Brands". Vol. 13(3), 339.

Founier, S. (1998). "Consumer and their brands: developing relationship theory in consumer research". Journal of Consumer Research, Vol. 24, 343-373.

Hair, J. F., Black, W. C., and Babin, B. J. (2010). Multivariate Data Analysis: A Global Perspective: Pearson Education.

Hollebeek, L. D., Glynn, M. S., and Brodie, R. J. (2014). "Consumer Brand Engagement in Social Media: Conceptualization, Scale Development and Validation". Vol. $28(2), 149$.

Huber, F., Meyer, F., and Schmid, D. A. (2015). "Brand love in progress - the interdependence of brand love antecedents in consideration of relationship duration". Vol. 24.

Hudson, S., Roth, M. S., Madden, T. J., and Hudson, R. (2015). "The effects of social media on emotions, brand relationship quality, and word of mouth: An empirical study of music festival attendees". Vol. 47, 68-68 - 76.

Hwang, J., and Kandampully, J. (2012). "The role of emotional aspects in younger consumer-brand relationships". Vol. 21, 98-108.

Jahn, B., and Kunz, W. (2014). A Brand Like a Friend - The Influence of Customer Engagement with Social Media Brand Pages on Brand Relationships and Loyalty Intentions. 
Jurisic, B., and Azevedo, A. (2011). "Building customer-brand relationships in the mobile communications market: The role of brand tribalism and brand reputation". Vol. $18(4 / 5), 349-366$.

Kapferer, J. N. (2008). The New Strategic Brand Management: Creating and sustaining brand equity long term (4th edition ed.): Kogan Page Limited.

Kline, R. B. (2011). Principles and Practice of Structural Equation Modeling: Guilford Publications.

Kudeshia, C., Sikdar, P., and Mittal, A. (2016). "Spreading love through fan page liking: A perspective on small scale entrepreneurs". Computers in Human Behaviour, Vol. 56, 257-270.

Langner, T., Bruns, D., Fischer, A., and Rossiter, J. R. (2014). "Falling in love with brands: a dynamic analysis of the trajectories of brand love". Vol.

Malhotra, N. K. (2007). Marketing research: an applied orientation: Pearson/Prentice Hall.

Malhotra, N. K. (2009). Marketing Research: An Applied Orientation: Prentice Hall.

Marôco, J. (2010). Análise de Equações Estruturais: Fundamentos teóricos, software \& Aplicações: REPORTNUMBER.

Moraes, C., Michaelidou, N., and Meneses, R. W. (2014). "The use of Facebook to promote drinking among young consumers". Vol. 30.

Nisar, T. M., and Whitehead, C. (2016). "Brand interactions and social media: Enhancing user loyalty through social networking sites". Vol. 62 .

Pagani, M., and Mirabello, A. (2011). "The Influence of Personal and Social-Interactive Engagement in Social TV Web Sites". Vol. 16(2), 41.

Palmatier, R. W., Houston, M. B., Dant, R. P., and Grewal, D. (2013). "Relationship Velocity: Toward A Theory of Relationship Dynamics". Vol. 77.

Park, C. W., MacInnis, D. J., and Priester, J. (2006). "Brand attachment: Constructs, consequences, and causes". Foundations and Trends in Marketing, Vol. 1(3), 191230.

Park, C. W., MacInnis, D. J., Priester, J., Eisingerich, A. B., and Iacobucci, D. (2010). "Brand Attachment and Brand Attitude Strength: Conceptual and Empirical Differentiation of Two Critical Brand Equity Drivers". Vol. 74. 
Park, N., Kee, K. F., and Valenzuela, S. (2009). "Being immersed in social networking environment: Facebook groups, uses and gratifications, and social outcomes". Vol. 12(6), 729.

Patwardhan, H., and Balasubramanian, S. K. (2011). "Brand romance: a complementary approach to explain emotional attachment toward brands". Vol. 20(4), 297-308.

Patwardhan, H., and Balasubramanian, S. K. (2013). "Reflections on emotional attachment to brands: Brand romance and brand love". Vol. 12.

Pedeliento, G., Andreini, D., Bergamaschi, M., and Salo, J. (2015). "Brand and product attachment in an industrial context: The effects on brand loyalty". Vol.

Sashittal, H. C., Hodis, M., and Sriramachandramurthy, R. (2015). "Entifying your brand among Twitter-using millennials". Vol. 58.

Schivinski, B., Christodoulides, G., and Dabrowski, D. (2016). "Measuring consumers' engagement with brand-related social-media content: development and validation of a scale that identifies levels of social-media engagement with brands". Journal of Advertising Research, Vol. 56(1), 64.

So, J. T., Parsons, A. G., and Yap, S. F. (2013). "Corporate branding, emotional attachment and brand loyalty: The case of luxury fashion branding". Vol. 17(4), 403-423.

Sternberg, R. J. (1986). "A triangular theory of love". Psychological Review, Vol. 93, 119-135.

Swimberghe, K. R., Astakhova, M., and Wooldridge, B. R. (2014). "A new dualistic approach to brand passion: Harmonious and obsessive". Vol. 67, 2657-2665.

Thomson, M., MacInnis, D. J., and Whan Park, C. (2005). "The Ties That Bind: Measuring the Strength of Consumers' Emotional Attachments to Brands". Vol. 15(1), 77-91.

Vernuccio, M., Pagani, M., Barbarossa, C., and Pastore, A. (2015). "Antecedents of brand love in online network-based communities. A social identity perspective". Vol. 24(7), 706-719.

Wallace, E., Buil, I., and Chernatony, L. d. (2014). "Consumer engagement with selfexpressive brands: brand love and WOM outcomes". Journal of Product \& Brand Management, Vol. 23(1), 33-42. 
Zhong, H., and Zhang, Y. (2013, 2013-01-01). Brand passionate consumption: What is it? How does it work? 


\section{Attachments}

\section{Attachment 1 - Survey 1}

\section{INQUÉRITO}

O presente questionário insere-se no âmbito de uma investigação académica do Mestrado em Marketing da Faculdade de Economia da Universidade do Porto sobre a relação do consumidor com as marcas num contexto digital.

A seleção das marcas em análise foi conseguida a partir de análise das marcas de consumo mais populares nas redes sociais, dentro da categoria "fashion". Nesse sentido assume-se que os inqueridos terão conhecimento de pelo menos uma das marcas em estudo.

Se não conhecer nenhuma marca exposta, ou não possuir conta no Facebook ou Instagram, por favor não responda a este questionário.

Os resultados deste questionário são completamente confidenciais e anónimos e destinam-se a fins académicos.

Para mais informações pode entrar em contacto a partir de up201000817@ @ep.up.pt

Desde já agradeço a disponibilidade para resposta a este inquérito de avaliação.

Ana Rita Sousa

\section{Tem uma conta em alguma rede social?}

- $\operatorname{Sim}$

- Não - se responder não passa para a pergunta 16

2. Se sim, qual ou quais?

- Facebook

- Instagram

- Linkedin 
- Google +

- Pinterest

- Twitter

- Youtube

- Outra. Qual?

3. Indique qual considera ser o nível de importância que atribui aos media sociais em que está registado (sendo 1=nenhuma importância e 7=extrema importância) (escrever um numero de 1 a 7)

$2^{\mathrm{a}}$ parte

4. Da lista apresentada abaixo, selecione a marca que mais gosta (ignorando o fator económico e considerando apenas o seu gosto pessoal):

- Converse

- Adidas Originals

- $\mathrm{H} \& \mathrm{M}$

- Victoria's Secret

- Zara

- Levi's

- Louis Vuitton

- Burberry

- Michael Kors

- Chanel

Obs. A partir deste momento as respostas devem ter como base a marca selecionada.

5. Em que rede social segue a marca escolhida?

- Instagram

- Facebook

- Em ambas

- Nenhuma (passe para a pergunta 9)

6. Em relação à marca escolhida indique o seu grau de concordância/discordância em relação a cada uma das afirmações (sendo $1=$ discordo totalmente e $7=$ concordo totalmente) atendendo aos motivos 
pelos quais segue a marca no Facebook e/ou Instagram: (escrever um número de 1 a 7)

- Considero os produtos daquela marca únicos

- Para ver as minhas dúvidas/questões resolvidas

- Para me fazer parecer "cool" em frente aos meus amigos

- Para saber mais sobre a marca

- Para conseguir obter interação direta com a empresa

- Para conseguir interagir com pessoas como eu na página de fãs desta marca

7. Pensando na rede social da marca escolhida indique como se posiciona em relação a cada uma das seguintes afirmações (sendo 1=discordo totalmente e 7=concordo totalmente): (escrever um número de 1 a 7)

- Leio post relacionados com esta marca nas redes sociais

- Leio/consulto páginas de fãs relativas a esta marca em sites de media sociais

- Observo imagens/gráficos relacionados com esta marca

- Sigo blogs relacionados com esta marca

- Comento vídeos relacionados com esta marca

- Comento posts relacionados com esta marca

- Comento imagens/gráficos relacionados com esta marca

- Partilho conteúdo relacionado com esta marca

- Faço Like em imagens/gráficos relacionados com esta marca

- Faço Like em posts relacionados com esta marca

8. Em relação à marca escolhida indique o seu grau de concordância/discordância em relação a cada uma das afirmações (sendo 1=discordo totalmente e $7=$ =concordo totalmente) pensando na rede social desta marca: (escrever um número de 1 a 7)

- Socializo bastante na rede social desta marca

- Contribuo para as discussões/conversas na rede social desta marca

- Estou tão interessado nas interações e opiniões dos outros utilizadores como estou no tipo de conteúdos que a rede social desta marca proporciona

- Uma das principais razoes porque gosto tanto da rede social desta marca é pelo que absorvo e aprendo com os outros utilizadores

- Esta página faz um bom trabalho a obter feedback e contributos dos seus visitantes 
- Gostaria de conhecer outros utilizadores que visitam regularmente a rede social desta marca

- Interessei-me por coisas que não me interessaria se não fosse por outros utilizadores desta página.

- No geral, os visitantes desta página têm bastante conhecimento dos tópicos abordados pelo que consigo aprender muito com eles

3.a parte

9. Em relação à marca escolhida indique o seu grau de concordância/discordância (sendo $1=$ discordo totalmente e $7=$ concordo totalmente) em relação a cada uma das afirmações: (escrever um número de 1 a 7)

- Esta é uma marca magnífica

- Esta marca faz-me sentir bem

- Esta marca é incrível

- Esta marca deixa-me muito feliz

- Adoro esta marca

- Esta marca é encantadora

- Sou um grande entusiasta desta marca

- Sinto-me bastante ligado/conectado com esta marca - além do número selecionar o adjetivo que acha mais correto

10. Em relação à marca escolhida indique o seu grau de concordância/discordância (sendo $1=$ discordo totalmente e $7=$ concordo totalmente) em relação a cada uma seguintes afirmações: (escrever um número de 1 a 7)

- Sinto que esta marca é como um amigo

- Sinto-me emocionalmente ligado a esta marca

- Tenho uma conexão especial com esta marca.

11. Em relação à marca escolhida indique o seu grau de concordância/discordância (sendo 1=discordo totalmente e 7=concordo totalmente) atendendo a cada uma seguintes afirmações: (escrever um número de 1 a 7)

- Esta marca simboliza o tipo de pessoa que sou

- Esta marca reflete a minha personalidade 
- Esta marca é uma extensão do meu interior/personalidade além do número selecionar a palavra que acha mais correta

- Esta marca reflete o que realmente sou

- Esta marca contribui para a minha imagem.

- Esta marca adiciona valor ao papel que desempenho socialmente.

- Esta marca tem um impacto positivo no que os outros pensam de mim.

- Esta marca melhora a forma como a sociedade me vê.

12. Em relação à marca escolhida indique o seu grau de concordância/discordância com as afirmações apresentadas abaixo (sendo 1=discordo totalmente e 7=concordo totalmente): (escrever um número de 1 a 7)

- Vou comprar esta marca da próxima vez que comprar um produto deste género

- Tenciono continuar a comprar esta marca

- Estou comprometido com esta marca

- Sinto-me disposto a pagar um preço mais elevado por esta marca em relação a outras

- Esta é a única marca, dentro desta categoria de produto, que eu compro.

- Quando vou às compras sinto-me indiferente às marcas concorrentes

- Se o produto desta marca estiver esgotado, adio a minha compra ou procuro outra loja que o tenha

- Prefiro passar sem do que comprar outra marca.

13. Em relação à marca escolhida indique o seu grau de concordância/discordância (sendo $1=$ discordo totalmente e $7=$ =concordo totalmente) atendendo a cada uma seguintes afirmações: (escrever um número de 1 a 7)

- Já recomendei esta marca a muitas pessoas

- Falo desta marca com os meus amigos

- Tento difundir boas recomendações sobre esta marca

- Faço muito passa-a-palavra positivo sobre esta marca.

14. Em relação à marca escolhida indique o seu grau de concordância/discordância (sendo $1=$ discordo totalmente e $7=$ =concordo totalmente) atendendo a cada uma seguintes afirmações: (escrever um número de 1 a 7) 
- Esta marca reflete o que eu sou

- Identifico-me com esta marca.

- Esta marca é a minha cara

15. Tendo em conta a página de Facebook/Instagram da marca escolhida

- Recomendaria a página junto dos meus amigos

- Não recomendaria a página junto dos meus amigos

16. Relativamente à criação de uma conta numa rede social:

- Pondero criar no futuro

- Não pondero criar no futuro

$4^{\mathrm{a}}$ parte

17. Sexo

- Feminino

- Masculino

18. Faixa etária

- Menos de 18 anos

- $18-25$

- 26-35

- 36-50

- Mais de 50

19. Grau de escolaridade

- Ensino Básico (até ao 9. ${ }^{\circ}$ ano)

- Ensino Secundário (até ao $12 .^{\circ}$ ano)

- Licenciatura

- Mestrado ou Doutoramento

20. Ocupação:

- Estudante

- Trabalhador por conta própria

- Trabalhador por conta de outrem

- Reformado

- Desempregado

Muito obrigada. 


\section{Attachment 2 - Survey 2}

\section{INQUÉRITO}

O presente questionário insere-se no âmbito de uma investigação académica do Mestrado em Marketing da Faculdade de Economia da Universidade do Porto sobre a relação do consumidor com as marcas num contexto digital.

A seleção das marcas em análise foi conseguida a partir de análise das marcas de consumo mais populares nas redes sociais, dentro da categoria "technology". Nesse sentido assume-se que os inqueridos terão conhecimento de pelo menos uma das marcas em estudo.

Se não conhecer nenhuma marca exposta, ou não possuir conta no Facebook ou Instagram, por favor não responda a este questionário.

Os resultados deste questionário são completamente confidenciais e anónimos e destinam-se a fins académicos.

Para mais informações pode entrar em contacto a partir de up201000817@fep.up.pt

Desde já agradeço a disponibilidade para resposta a este inquérito de avaliação.

Ana Rita Sousa

Secção 1:

\section{Tem uma conta em alguma rede social?}

- $\operatorname{Sim}$

- Não - se responder não passa para a pergunta 16

Secção 2:

\section{Se sim, qual ou quais?}

- Facebook 
- Instagram

- Linkedin

- Snapchat

- Twitter

- Pinterest

- Youtube

- Google +

- Outra. Qual?

23. Indique qual considera ser o nível de importância que atribui aos media sociais em que está registado (sendo 1=nenhuma importância e 7=extrema importância) (escrever um numero de 1 a 7)

Secção 3:

24. Relativamente à criação de uma conta numa rede social:

- Pondero criar no futuro

- Não pondero criar no futuro

Secção 4

25. Da lista apresentada abaixo, selecione a marca com que mais e identifica (ignorando o fator económico e considerando apenas o seu gosto pessoal):

- Huawei

- Microsoft Lumia

- Samsung

- Intel

- PlayStation

- Blackberry

- Asus

- Sony

- Netflix

- Itunes

- Amazon

- Spotify 
Nota 1: A Apple não foi considerada na lista de opções por não estar presente nas redes sociais alvo deste estudo.

Obs. A partir deste momento as respostas devem ter como base a marca selecionada.

\section{Em que rede social segue a marca escolhida?}

- Facebook

- Instagram

- Em ambas

- Nenhuma (passe para a pergunta 9)

\section{Secção 5}

27. Tendo em conta a(s) página(s) de Facebook/Instagram da marca escolhida:

- Recomendaria a página junto dos meus amigos

- Não recomendaria a página junto dos meus amigos

28. Em relação à marca escolhida indique o seu grau de concordância/discordância em relação a cada uma das afirmações (atendendo aos motivos pelos quais segue a marca no Facebook e/ou Instagram: (escrever um número de 1 a 7)

- Considero os produtos daquela marca únicos

- Para ver as minhas dúvidas/questões resolvidas

- Para me fazer parecer "cool" em frente aos meus amigos

- Para saber mais sobre a marca (ex. novidades, produtos)

- Para conseguir obter interação direta com a empresa

- Para conseguir interagir com pessoas como eu na página de fãs desta marca

29. Pensando na rede social da marca escolhida indique como se posiciona em relação a cada uma das seguintes: (escrever um número de 1 a 7)

- Leio post relacionados com esta marca nas redes sociais

- Leio/consulto páginas de fãs relativas a esta marca em sites de media sociais

- Observo imagens/gráficos relacionados com esta marca 
- Sigo blogs relacionados com esta marca

- Comento vídeos relacionados com esta marca

- Comento posts relacionados com esta marca

- Comento imagens/gráficos relacionados com esta marca

- Partilho conteúdo relacionado com esta marca

- Faço Like em imagens/gráficos relacionados com esta marca

- Faço Like em posts relacionados com esta marca

\section{Em relação à marca escolhida indique o seu grau de} concordância/discordância em relação a cada uma das afirmações pensando na rede social desta marca: (escrever um número de 1 a 7)

- Socializo bastante na rede social desta marca

- Contribuo para as discussões/conversas na rede social desta marca

- Estou tão interessado nas interações e opiniões dos outros utilizadores como estou no tipo de conteúdos que a rede social desta marca proporciona

- Uma das principais razões porque gosto tanto da rede social desta marca é pelo que absorvo e aprendo com os outros utilizadores

- Esta página faz um bom trabalho a obter feedback e contributos dos seus visitantes

- Gostaria de conhecer outros utilizadores que visitam regularmente a rede social desta marca

- Interessei-me por coisas que não me interessaria se não fosse por outros utilizadores desta página.

- No geral, os visitantes desta página têm bastante conhecimento dos tópicos abordados pelo que consigo aprender muito com eles

Secção 6

31. Em relação à marca escolhida indique o seu grau de concordância/discordância em relação a cada uma das afirmações: (escrever um número de 1 a 7)

- Esta é uma marca magnífica

- Esta marca faz-me sentir bem

- Esta marca é incrível

- Esta marca deixa-me muito feliz

- Adoro esta marca

- Esta marca é encantadora

- Sou um grande entusiasta desta marca

- Sinto-me bastante ligado a esta marca- 
32. Em relação à marca escolhida indique o seu grau de concordância/discordância em relação a cada uma seguintes afirmações: (escrever um número de 1 a 7 )

- Sinto que esta marca é como um amigo

- Sinto-me emocionalmente ligado a esta marca

- Tenho uma conexão especial com esta marca.

33. Em relação à marca escolhida indique o seu grau de concordância/discordância) atendendo a cada uma seguintes afirmações: (escrever um número de 1 a 7)

- Esta marca simboliza o tipo de pessoa que sou

- Esta marca reflete a minha personalidade

- Esta marca é uma extensão do meu interior

- Esta marca reflete o que realmente sou

- Esta marca contribui para a minha imagem.

- Esta marca adiciona valor ao papel que desempenho socialmente.

- Esta marca tem um impacto positivo no que os outros pensam de mim.

- Esta marca melhora a forma como a sociedade me vê.

34. Em relação à marca escolhida indique o seu grau de concordância/discordância atendendo a cada uma seguintes afirmações: (escrever um número de 1 a 7)

- Esta marca reflete o que eu sou

- Identifico-me com esta marca.

- Esta marca é a minha cara

35. Em relação à marca escolhida indique o seu grau de concordância/discordância com as afirmações apresentadas abaixo: (escrever um número de 1 a 7)

- Vou comprar esta marca da próxima vez que comprar um produto deste género 
- Tenciono continuar a comprar esta marca

- Estou comprometido com esta marca

- Sinto-me disposto a pagar um preço mais elevado por esta marca em relação a outras

- Esta é a única marca, dentro desta categoria de produto, que eu compro.

- Quando vou às compras sinto-me indiferente às marcas concorrentes

- Se o produto desta marca estiver esgotado, adio a minha compra ou procuro outra loja que o tenha

- Prefiro passar sem do que comprar outra marca.

\section{Em relação à marca escolhida indique o seu grau de concordância/discordância atendendo a cada uma seguintes afirmações: (escrever um número de 1 a 7 )}

- Já recomendei esta marca a muitas pessoas

- Falo desta marca com os meus amigos

- Tento difundir boas recomendações sobre esta marca

- Faço muito passa-a-palavra positivo sobre esta marca.

Secção 7:

37. Sexo

- Feminino

- Masculino

38. Faixa etária

- Menos de 18 anos

- $18-25$

- 26-35

- 36-50

- Mais de 50

39. Grau de escolaridade

- Ensino Básico (até ao 9..$^{\circ}$ ano)

- Ensino Secundário (até ao $12^{\circ}$ ano)

- Licenciatura

- Mestrado ou Doutoramento

- Outra opção 
40. Ocupação:

- Estudante

- Trabalhador Estudante

- Empregado/Trabalhador

- Desempregado

- Reformado

Muito obrigada. 